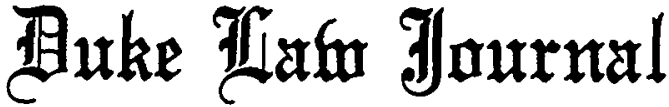

VOLUME 1982

DECEMBER

NUMBER 6

\section{SEARCHING FOR THE CORPORATION'S \\ VOICE IN DERIVATIVE SUIT \\ LITIGATION: A CRITIQUE OF \\ $Z A P A T A$ AND THE ALI PROJECT}

\author{
JAMES D. CoX*
}

Like the heroine in a Saturday natinee, the derivative suit has repeatedly appeared to be at the cliffs of disaster. The adoption of security for expense statutes, ${ }^{1}$ the enactment of broadly permissive indemnification statutes, ${ }^{2}$ and even the judicial tightening of pleading requirements against derivative suit defendants ${ }^{3}$ have each been proclaimed in turn as the death knell of the derivative suit. Despite concern that these developinents would raise to impossible heights the hurdles the plaintiff inust cross to reach the jury, the derivative suit has remained a viable legal institution. ${ }^{4}$ Now, however, it is threatened by

* Professor of Law, Duke University. Comments by Professor Deborah A. DeMott to an earher draft of the manuscript were most helpful in preparing this article. The author also benefited from the research assistance of Messrs. Timothy J. Pakenham, James C. Reilly, and Jeffrey D. Sternklar, members of the current graduating class.

1. See Hornstein, New Aspects of Stockholders' Derivative Suits, 47 Colum. L. REv. 1, 4-7 (1947); Hornstein, The Future of Corporate Control, 63 HARv. L. REv. 476, 476 (1950); Note, Security for Expenses Legislation-Summary, Analysis, and Critique, 52 ColuM. L. REv. 267, 26869 (1952).

2. See, e.g., Bishop, Sitting Ducks and Decoy Ducks: New Trends in the Indemnification of Corporate Directors and Officers, 77 YALE L.J. 1078 (1968).

3. See, e.g., Dykstra, The Revival of the Derivative Suit, 116 U. PA. L. REv. 74 (1967).

4. The aggregate data refiects a modest increase during the $1970 \mathrm{~s}$ im both the number of shareholder suits and the incidence of disputed events. See Jones, An Empirical Examination of the Incidence of Shareholder Derivative and Class Action Lawsuits, 1971-1978, 60 B.U.L. REv. 306 (1980). However, when suits involving questionable corporate payments are elimimated from the data base because they appear to have been an isolated phenomenon, "the imcidence of shareholder suits may actually be declining." Id. at 323. The decline, however, is as likely a function of burgeoning hitigation costs, which have a disproportionate impact on contingency fee hitigation, as it is a result of the procedural obstacles to suit. When litigation is costly, and the outcome is 
a new and uniquely powerful assailant, the product of a creative mix of doctrine and enabling statute, that gives the corporation an imdependent will and a voice to express that will in a derivative suit involving a majority of its directors. This latest threat to the derivative suit is the special litigation committee, an evolutionary response to earlier, relatively inefficient and ineffective procedural devices designed to terminate derivative suits.

This article analyzes both the current law governing special litigation committees and proposals to change the law. As a starting point, it assumes that the corporation has a legitimate interest in raising at any stage in the litigation its concern that a derivative suit does it nore harm than good. A derivative suit against managers or directors may ultimately lead to charges against the corporation for the defendant's litigation costs, ${ }^{5}$ the corporation's own litigation costs incident to its participation as a nominal defendant, and the more indefinite costs associated with any litigation, such as loss of inorale, deflection of einployee time, and injury to the corporate reputation. Even if the defendant's fault is conceded, the recoverable aniount after deduction of the attorney's fees of the plaintiff niay be insufficient to cover the costs of the suit; if the convplaint is less well-founded, the cost-benefit ratio is even higher.

The derivative suit plaintiff is self-selected; without election or appointment he presents himself as spokesnian for the corporate interest. Because the plaintiff usually has no significant financial interest in the corporation, the possibly harmful economic effects of prosecuting the suit cannot be expected to guide his decision to litigate. ${ }^{6}$ Although

uncertain, potential plaintiffs generally require a higher probability of winning before they will initiate a suit. An increase in risk aversion annong potential plaintiffs or an increase in litigation costs results in a reduction in the incidence of litigation. See Simon, Imperfect Information, Costly Litigation, and Product Quality, 12 BeLL. J. EcoN. 171 (1981).

5. If the defendants prevail, the corporation will certainly have to bear these costs.

6. Of course, the impact of a derivative suit, like that of any representative action, is not limited to its effect on the imitiating plaintiff; the whole plaintiff class lias an interest in the outcome. Derivative suits are distinguishable fron class actions because stockholders are inextricably attached, through their stock ownership, to the costs and benefits of the suit. In a class action, class ineinbers inay protect themselves froin the detrimental effects of a inisguided or wasteful prosecution by opting out of the plaintiff class. In a derivative suit, however, stockholders can escape class inembership only by terminating their interests in the corporation, and this may be too high a price to pay.

There was once a requirenent that the plaintiff seek stockholder approval before he initiatcd the suit, see, e.g., Hawes v. Oakland, 104 U.S. 450, 461 (1881), but this requirement is now regarded as inefficient and inexpedient. See, e.g., Interstate Refineries, Inc. v. Barry, 7 F.2d 548, 551-52 (8th Cir. 1925); Campbell v. Loew's, Inc., 36 Del. Ch. 533, 536-37, 134 A.2d 565, 567 (1957); Tevis v. Hammersmith, 31 Ind. App. 281, 66 N.E. 79, 82, affd, 161 Ind. 74, 67 N.E. 672 (1903); S. Solomont \& Sons Trust, Inc. v. New England Theatres Operating Corp., 326 Mass. 99, 114, 93 N.E.2d 241, 249 (1950); see also Bell v. Arnold, 175 Colo. 277, 282, 487 P.2d 545, 547-48 
some faint aura of legitimacy accrues to the plaintiff's authority to represent the corporate interest when the demand requirement has been excused, ${ }^{7}$ that aura is no substitute for the unique capability of the board of directors to analyze the costs and benefits of the suit from the corporate perspective. ${ }^{8}$ The special litigation committee remedies the problem by providing a voice for the corporation even after the court has excused the demand requirement. ${ }^{9}$

(1971); Mountain States Packing Co. v. Curtis, 86 Colo. 355, 281 P. 737 (1929); Claman v. Robertson, 164 Ohio St. 61, 128 N.E.2d 429 (1955).

7. The demand requirement conditions the initiation of a derivative suit on the plaintiff's notifying the board of directors of his complaint; this notice gives the board the opportunity to assume control of the decision to hitigate. Brody v. Chemical Bank, 517 F.2d 932, 934 (2d Cir. 1975). Directors are highly unlikely to respond favorably to a demand for suit, especially when their colleagues may be named as defendants. If an independent board decides in good faith against hitigation (rejects the demand), the suit is almost always dismissed, see, eg., Cramer v. GTE, 582 F.2d 259 (3d Cir. 1978); Robinson v. Caster, 356 F.2d 924, 927 (7th Cir. 1966), although the plaintiff may be granted leave to amend his complaint, see Abramowitz v. Posner, $513 \mathrm{~F}$. Supp. 120, 125 (S.D.N.Y. 1981), affd, 672 F.2d 1025 (2d Cir. 1982). Only in rare cases will courts allow the plaintiff to proceed after a rejected deinand. See, e.g., Ashwander v. TVA, 297 U.S. 288 (1936); Galef v. Alexander, 615 F.2d 51, $59-61$ (2d Cir. 1980); Miller v. AT\&T, 507 F.2d 759 (3d Cir. 1974); Ash v. IBM, 353 F.2d 491 (3d Cir. 1965), cert. denied, 384 U.S. 927 (1966); Higgins v. Shenago Pottery Co., 256 F.2d 504 (3d Cir. 1958), cert. denied, 364 U.S. 899 (1960); Swanson v. Traer, 249 F.2d 854 (7th Cir. 1957). Therefore, most derivative suits that survive the denand requirement are suits in which the court excuses the requirement because the plaintiff pleads facts that imphicate a majority of the board in the alleged misconduct. See, e.g., Nussbacher v. Continental Ill. Nat'l Bank \& Trust Co., 518 F.2d 873, 877 (7th Cir. 1975), cert. denied, 424 U.S. 928 (1976); In re Kauffman Mut. Fund Actions, 479 F.2d 257 (1st Cir. 1973), cert. denied, 414 U.S. 857 (1974). See generally Note, The Demand and Standing Requirements in Stockholder Derivative Actions, 44 U. CHI. L. REv. 168 (1976). The futihty of expecting the corporation to conduct the suit under such circumstances legitimizes by default the plaintiff's authority to act in its stead.

8. See Joy v. North, [Current] Fed. SEC. L. Rep. (CCH) ๆ 98,860 at 94,440 (2d Cir. 1982) (recognizing the value of the directors' perspective on the suit's legitimacy). A few courts have imdicated in dicta that the plaintiff has to make a greater showing of director involvement to excuse the demand than to persuade the court to ignore the decision of the directors not to maintain the suit. See Clark v. Lomas \& Nettleton Fin. Corp., 625 F.2d 49, 54 n.5 (5th Cir. 1980), cert. denied, 450 U.S. 1029 (1981); Galef v. Alexander, 615 F.2d 51, 59 (2d Cir. 1980); Heit v. Baird, 567 F.2d 1157, 1162 n.6 (1st Cir. 1977). It may seem futile to require a demand when the court will not heed the board's decision not to hitigate. See Lewis v. Curtis, 671 F.2d 779 (3d Cir.), cert. denied, 51 U.S.L.W. 3258 (U.S. Oct. 5, 1982). On the other hand, the demand requirenent in such cases is no burden to the plaintiff, and it affords the directors an opportunity to express the corporate voice and to take control of the hitigation should they decide that the suit would be beneficial.

Section 36(b) of the Investment Company Act of 1940, 15 U.S.C. $\S 80 \mathrm{a}-35$ (b) (1976), best illustrates this attitude toward the demand requirement. Section 36(b) requires a court to give only such weight as it beheves reasonable to director approval of the suspect transaction, $i d$, and section 11(a) requires that $40 \%$ of the directors be independent before the board is empowered to reject a demand, id. $\S 80$ (a)-10(a). Nevertheless, courts applying section $36(\mathrm{~b})$ have required that a demand be made even if the court is likely to find board approval unreasonable or if the board does not satisfy the independence requirement. See infra note 103 (cases cited).

9. A special hitigation committee may be created before or after a derivative suit has been filed. The full board creates the committee and staffs it with directors who are not implicated in the derivative suit. This is consistent with the broadly permissive scope of contemporary corpo- 
Commentators have explained in detail why the special hitigation committee's independence may be more apparent than real. ${ }^{10}$ Their concern is founded on the observation that the defendants and the nembers of the special hitigation committee share a common cultural bond: directorship of a public corporation. ${ }^{11}$ The natural empathy and collegiahty that this bond engenders makes an adverse judgment of a colleague's behavior distasteful at best. Also, when the committee is formed after the instigation of the derivative suit, the situation is rife with opportunities for the defendants to select for committee membership those directors most sympathetic to their position. The committee's independence may be further undermined by its nembers' desire to curry favor with their fellow directors or with the business conimunity in general. Fimally, special litigation committees operate under the constant threat of dissolution should they displease the board by pursuing the plaintiff's cause with excessive zeal.

The likelihood that these factors will corrupt the committee's independent judginent will be referred to as "structural bias."12

ratc statutes governing corporate executive committees. See, e.g., CAL. CoRP. CodE $\S 311$ (W'est Supp. 1981); Del. Code ANN. tit. 8 \& 141(c) (1953); N.J. STAT. ANN. § 14A:6-9 (West 1974); N.Y. Bus. CoRP. Law \& 712(a) (McKinney Supp. 1981). See generally Aurell, The Corporate Executive Committee: A Dilemma for the Nonmember Director, 17 U. FLA. L. REv. 525 (1965); McMullen, Committees of the Board of Directors, 29 Bus. LAw. 755 (1974); Comment, Exapcutive CommitteesCreation, Procedures, and Authority, 1967 WASH. U.L.Q. 42.

The committee must determme whether prosecution of a derivative suit is in the corporation's best interest. It is enpowcred to take any stcps reasonably necessary to impleinent its decision, and usually instructs corporate counsel to prosecute the suit or to move for its dismissal. Vital to the committee's efficacy is its power, frequently recognized in the corporate statutes, to cloak its actions with the protection of the business judgment rule even when the board as a whole is preventcd by allegations of self-interest froin evoking the rule. See, e.g., Ash v. Brunswick Corp., 405 F. Supp. 234 (D. Del. 1975); Forman v. Chesler, 39 Del. 484, 167 A.2d 442 (1961); Beard v. Elster, 39 Del. 153, 160 A.2d 731 (1960); Stemerman v. Ackerman, 40 Del. Ch. 431,184 A.2d 28 (1962); Sorm v. Shahmoon Indus., 30 Misc. 2d 429, 220 N.Y.S.2d 760 (Sup. Ct. 1961). For a discussion of the potential liability of disinterested cxecutive committees, see Hahn and Manzoni, The Monitoring Committee and Outside Directors' Evolving Duty of Care, 9 LoY. U. CHI. L.J. 587 (1978).

10. See, e.g., Coffee, Beyond the Shut-Eyed Sentry: Toward A Theoretical View of Corporate Misconduct and an Effective Legal Response, 63 VA. L. REv. 1099 (1977); Dent, The Power of Directors to Terminate Shareholder Litigation: The Death of the Derivative Suit, 75 Nw. U.L. Rev. 96 (1980); Comment, A Procedural Treatment of Derivative Dismissal by Minority Directors, 69 CAL. L. REv. 885 (1981); Note, The Business Judgment Rule in Derivative Suits Against Directors, 65 CoRnell L. Rev. 600 (1980).

11. The Delaware Supreme Court recently dcscribed this type of empathy between fellow directors as a " 'there but for the grace of God, go I' " attitude. Zapata Corp. v. Maldonado, 430 A.2d 779, 787 (Del. 1981).

12. Outside counsel advising the special hitigation committee may also be under the influence of these same corrupting pressures; corporate counscl are socialized to the defendant's point of view through years of representing corporations and their directors and officers. Mcinbers of the plaintiff' bar are never chosen as counsel to the special litigation committee. 
Whatever one's view about the impact of the factors that feed a committee's structural bias, the committee's record is itself disquieting: although there have been more than a score of special litigation committee cases to date, ${ }^{13} \mathrm{im}$ all but one the committee concluded that the suit in question was not in the corporation's best interest. ${ }^{14}$

Part I of this article describes the evolution of the special litigation committee as a result of the ineffectiveness of other procedural devices designed to enable corporations to rid themselves of unwanted derivative suits. ${ }^{15}$ Parts II and III critically examine various standards for

13. See, e.g., Gaines v. Haughton, 645 F.2d 761 (9th Cir. 1981), cert. denied, 102 S. Ct. 1006 (1982); Lewis v. Anderson, 615 F.2d 778 (9th Cir.), cert. denied, 449 U.S. 869 (1980); Abbey v. Control Data Corp., 603 F.2d 724 (8th Cir. 1979), cert. denied, 444 U.S. 1017 (1980); Cramer v. GTE, 582 F.2d 259 (3d Cir. 1978); Watts v. Des Moines Register \& Tribune, 525 F. Supp. 1311 (S.D. Iowa 1981); Abramowitz v. Posner, 513 F. Supp. 120 (S.D.N.Y. 1981), affd, 672 F.2d 1025 (2d Cir. 1982); Genzer v. Cunningham, 498 F. Supp. 682 (E.D. Mich. 1980); Abella v. Universal Leaf Tobacco Co., 495 F. Supp. 713 (E.D. Va. 1980); Maher v. Zapata Corp., 490 F. Supp. 348 (S.D. Tex. 1980); Maldonado v. Flynn, 485 F. Supp. 274 (S.D.N.Y. 1980), modified, 671 F.2d 729 (2d Cir. 1982); Rosengarten v. ITT Corp., 466 F. Supp. 817 (S.D.N.Y. 1979); Gall v. Exxon Corp., 418 F. Supp. 508 (S.D.N.Y. 1976); Lasker v. Burks, 404 F. Supp. 1172 (S.D.N.Y. 1975) (motion to disıniss denied without prejudice to renew and discovery ordered), 426 F. Supp. 844 (S.D.N.Y. 1977) (summary judgment granted), rev'd, 567 F.2d 1208 (2d Cir. 1978), rev'd, 441 U.S. 471 (1979); Siegal v. Merrick, 84 F.R.D. 106 (S.D.N.Y. 1979); Maldonado v. Flynn, 413 A.2d 1251 (Del. Ch. 1980), rev'd sub nom. Zapata Corp. v. Maldonado, 430 A.2d 779 (Del. 1981); Swenson v. Thibaut, 39 N.C. App. 771250 S.E.2d 279 (1978); Falkenberg v. Baldwin, N.Y.L.J., Mar. 3, 1980, at 12, col.6 (N.Y. Sup. Ct. 1980); Auerbach v. Aldrich, N.Y.L.J. Dec. 23, 1977, at 13, col. 5 (N.Y. Sup. Ct. 1977); Auerbach v. Bennett, 47 N.Y.2d 619, 393 N.E.2d 994, 419 N.Y.S 2d 920 (1979); Parkoff v. GTE, 74 A.D.2d 762, 425 N.Y.S.2d 599 (1978), affd, 53 N.Y.2d 412, 425 N.E.2d 820, 442 N.Y.S.2d 432 (1981); Byers v. Baxter, 69 A.D.2d 343, 419 N.Y.S.2d 497 (1979); Wesheler v. Exxon Corp., 55 A.D.2d 875, 390 N.Y.S.2d 111 (1977); Sonics Int'1, Inc. v. Dorchester Enters., 593 S.W.2d 390 (Tex. Civ. App. 1980).

14. The lone blemish on the special litigation committee's otherwise spotless record of siding witl the defendant is Abramowitz v. Joy, North, No. B-77-385 (D. Conn. July 16, 1980); see also The Future of Stockholder Litigation in State and Federal Courts After Burks, Maldonado and Abramowitz, 6 DEL. J. OF CORP. LAw 556, 557 (1981).

15. The advent of the special litigation committee is also part of a inore sweeping inovennent toward depending on imdependent directors to inonitor managers. According to the inonitoring model, courts give special litigation committees preferred treatment in order to einphasize to the independent directors the responsibilities of their undertaking. Coffee, supra note 10, at 1237-41. The monitoring model is premised largely on beliefs of what the board can do, ratlier than on observations of what boards in fact do. See Eisenberg, Legal Models of Management Structure in the Modern Corporation: Officers, Directors, and Accountants, 63 CALlF. L. REv. 375 (1975); Eisenberg, The Legal Roles of Shareholders and Management in Modern Corporate Decisionmaking, 57 CALIF. L. REv. 1 (1969). Even those wlıo question the inonitoring model assume its desirability and restrict their criticisms to the inechanics of inonitoring. See, e.g., Brudney, The Independent Director-Heavenly City or Potemkin Village, 95 HARv. L. REv. 597 (1982); Werner, Corporation Law in Seareh of Its Future, 81 Colum. L. REv. 1611, 1663-66 (1981).

The directors' general ability to inonitor nanagement may suffer because the outside directors lack the time, the information, and the expertise to make meaningful performance evaluations, receive limited mcentives to perform an adequate job, are not subject to significant sanctions for a lackluster performance, and enjoy cultural and economic relationships with management that preclude an adversarial review. Sce Brudney, supra, at 616; DeMott, Reweaving the Corporate 
judicial review of special litigation committee decisions. They demonstrate that the Delaware Supreme Court's newfound sensitivity to the effects of structural bias on the special litigation committee is more artificial than real and that the recent proposal before the American Law Institute (the "ALI") is predicated on a wholesale misconception of the issue. The article concludes with a suggestion for redefining the way in which the parties and the courts evaluate the corporation's interest in the contmuation of a derivative suit.

\section{The Special Litigation Committee as the Most Effective Means of Terminating Derivative Suits}

An entire set of derivative suit procedures, including the demand requirement, are anchored in the belief that corporations need to be able to rid themselves of actions that are likely to do thein inore harm than good. The corporation or the defendants may tliwart the suit soon after its imception by a request that the plaintiff post security for expenses or by a pretrial unotion for summary judgment or dismissal. Alternatively, the corporation may bypass the plaintiff and reacli an outof-court settlement with the defendant.

These procedures are used infrequently, however, because they each have significant drawbacks that either erode their effectiveness or render them unacceptable to the board of directors. The weaknesses of these procedures created the impetus for the development of special litigation committees as a new means of protecting the corporation from unwanted derivative suits. The committee is a lineal descendant of these maladapted ancestors and draws on thein as a source of legitimacy as it remedies their inefficiencies.

\footnotetext{
Veil: Management Structure and the Control of Corporate Information, 41 LAw \& CONTEMP. PROBS. 182 (1977).

These criticisms are less serious in the context of the special litigation committee. The record to date suggests that the committee has not suffered from any lack of information. Whether the information it receives las been sanitized by management can be determined when the court, with the plaintiff's assistance, reviews the committee's work. See infro notes 89-90 and accompanying text. Because the committee relies heavily on counsel as fact gatherer and report drafter, it has sufficient time and expertise to thoroughly investigate the alleged improprieties. See, e.g., Rosengarten v. ITT Corp., 466 F. Supp. 817 (S.D.N.Y. 1979). Finally, the rewards and sanctions for the committee's work are embodied in the court's response to the recommendation. These circumstances suggest that the special litigation committee may be uniquely capable of fulfilling its monitoring function. On the other hand, members of special litigation committees are as likely as other directors to empathize with manageinent and to fall under the sway of structural bias.
} 


\section{A. Security for Expense Statutes.}

The legislative history indicates that New York's security for expense statute, the forerunner of statutes enacted in other states, was a response to the popular conception of the derivative suit plaintiff as one who traffics in corporate causes of action and initiates suits for the sole purpose of harassment or personal gain. ${ }^{16}$ The goal of the security for expense statute is to discourage the prosecution of unmeritorious claims against management. Within a decade of its enactment, however, the New York statute proved ineffective. ${ }^{17}$ Such statutes are rendered impotent by the common exemption ${ }^{18}$ for suits brought by a plaimtiff or plaintiffs who own five percent or inore of the corporation's outstanding stock or who own stock with a market value above $\$ 50,000$. If the original plaintiff does not meet these criteria, he inay obtain a stay after the motion for security is made, during which time he nnay procure a hist of stockholders and solicit their participation as plaintiffs im order to satisfy the ownership requirement. Board members inay prefer not to mvoke the statute at all rather than risk the adverse pubhicity that the plaintiff's solicitation would cause. ${ }^{19}$

Even if the board successfully invokes the statute and the court dismisses the suit for failure to post security, the disinissal is not an adverse judgment on the merits; the plaintiff may therefore initiate the suit $\mathrm{m}$ another state that does not have a security for expense statute. Finally, security for expense statutes do not apply to the increasing number of derivative suits predicated on the federal securities laws. For these reasons, state security for expense statutes offer inadequate, if not wholly illusory, protection from unwanted derivative suits. ${ }^{20}$ By contrast, a special hitigation committee may be used in any derivative suit to procure a final judgment for the defendants and to avoid the adverse publicity that may surround a plaintiff's solicitation of shareholder support for his cause.

16. For a concise summary of the legislative history, see Comment, Security for Expenses in Shareholders' Derivative Suits: 23 Years' Experience, 4 Colum. J.L. \& SOC. PROBS. 50, 50-53 (1968).

17. See Note, Security for Expenses Legislation-Summary, Analysis, and Critique, 52 COLUM. L. REv. 267, 281 (1952).

18. See, e.g., N.Y. Bus. CoRP. LAW $\$ 626$ (McKinney 1963).

19. Comment, supra note 16 , at $64-65$.

20. The recent amendment of the Model Busimess Corporation Act to delete its security for expense provision indicates that such provisions are imeffective. Report of Committee on Corporate Laws, Proposed Revisions of the Model Business Corporation Act Affecting Actions by Shareholders, 37 Bus. LAw. 261, 265-66 (1981). 


\section{B. Pretrial Motions.}

Some argue that the appropriate vehicle for the termination of an unwanted derivative suit is a motion for summary judgment or a motion to dismiss. ${ }^{21}$ These motions, however, are of limited benefit to the corporation. When ruling on a motion to dismiss, a court simply tests the sufficiency of the complaint, and a court only grants a motion for summary judgment if there are no disputed issues of material fact. ${ }^{22}$ The motions are particularly ineffective in state law actions for breach of fiduciary duty because it is easy to find factual disputes that have a material bearing on the outcome of such cases. ${ }^{23}$ The motions are somewhat more effective in suits under the federal securities laws because many of these suits are decided on purely legal issues, such as whether a private right of action exists or whether the requisite causality is present. ${ }^{24}$

To make a pretrial motion, the corporation must have standing to enter an active defense on the merits, ${ }^{25}$ but it is unclear under what circumstances the requisite standing exists. The corporation may de-

21. See, e.g., Principles of Corporate Governance and Structure: Restatement and Recommendations 325 (Tent. Draft No. 1, 1982) [hereinafter cited as Corporate GOVERNANCE].

22. 2A J. Moore \& J. Lucas, Moore's Federal Practice $\$ 12.08$ at 2274 (2d ed. 1982).

23. For a discussion of the weaknesses of state law sumnary judgment procedures, see Zack, California Summary Judgment: The Need for Legislative Reform, 59 CALIF. L. REv. 439, 453-64 (1971).

24. In attacks on questionable payment practices, derivative suit plaintiffs frequently atteinpt to rely on a disclosure violation of sections 13(a) and 14(a) of the Securities Exchange Act. See 15 U.S.C. $\$ 78 \mathrm{~m}(\mathrm{a}), 78 \mathrm{n}(\mathrm{a})$ (1976). Section 13(a) requires periodic reporting by certain public corporations, and section 14(a) regulates the solicitation of proxies. See Abbey v. Control Data Corp., 603 F.2d 724 (8th Cir. 1979), cert. denied, 444 U.S. 1017 (1980); Rosengarten v. ITT, 466 F. Supp. 817 (S.D.N.Y. 1979). The courts in Abbey and Rosengarten reviewed the substantive merits of the claims and disinissed the cases at the recommendation of special litigation counmittees, but the courts could have easily dismissed the cases under Rule 12(b)(6) for failure to state a clain on which relief could be granted. Courts have refused to allow an implied cause of action under section 13(a), see, e.g., In re Penn Central Sec. Litig., 494 F.2d 528 (3d Cir. 1974); McLaughlin v. Campbell, 410 F. Supp. 1321 (D. Mass. 1976); duPont v. Wyly, 61 F.R.D. 615 (D. Del. 1973); $c f$. Smith v. Murchison, 310 F. Supp. 1079, 1088 (S.D.N.Y. 1970) (dicta), and plaintiffs are often unable to show a causal relationship between proxy solieitation and the failure to disclose questionable payınents, see, e.g., Herman v. Beretta, [1978 Transfer Binder] FED. SEc. L. REP. (CCH) I 96,574 (S.D.N.Y. 1978); Limmer v. GTE, [1977-1978 Transfer Bimder] FED. SEC. L. REP. (CCH) I 96,111 (S.D.N.Y. 1977). But cf. Weisberg v. Coastal States Gas Corp., 609 F.2d 650 (2d Cir. 1979), cert. denied, 445 U.S. 951 (1980) (dismissal reversed to allow plaintiff to discover whether directors concealed bribery and received kickbacks). The Court of Appeals for the Nintli Circuit recently affirmed a summary judgment for the defendant directors in a suit under section 14(a). See Gaines v. Haughton, 645 F.2d 761 (9th Cir. 1981), cert. denied, 102 S. Ct. 1006 (1982). The Gaines court leld that although director misconduct involving a breach of trust or self-dealing ınust be disclosed in proxy inaterials that solicit the director's reelection, the statute does not require disclosure of simple breach of fiduciary duty or waste. $645 \mathrm{F.2d}$ at 779.

25. See infra note 78. 
fend on the merits when the plaintiff attacks an established method of doing business, ${ }^{26}$ but not if the plaintiff charges self-dealing or wasteful coinpensation. ${ }^{27}$ The corporation cannot rely on the real defendants to make the desired notion because the defendants may prefer to follow their own litigation strategy, especially when it is not clear that the corporation will ultimately reimburse their expenses. ${ }^{28}$ These hurdles are neatly avoided when a special litigation committee recommends dismissal.

Furthermore, using a special litigation committee allows the corporation to raise a broader array of issues in opposition to the derivative suit than either the corporation or the real defendants can raise in the context of a motion for summary judgment or a motion to dismiss. For exainple, if the defendants are charged with self-dealing, the case is likely to turn on questions of disclosure, independent approval of the transaction, the transaction's financial terms, and perhaps whether it advances the corporate interest. A special litigation committee's rec-

26. See, e.g., Otis \& Co. v. Pennsylvania R.R., 57 F. Supp. 680 (E.D. Pa. 1944), aff d, 155 F.2d 522 (3d Cir. 1946).

27. See, e.g., CAl. Corr. Code § 317(d) (West 1977); Del. Code ANN. tit. 8 § 145(c) (1974); N.Y. Bus. CoRP. LAW § 724(a) (McKinney 1963); MOdEL Business CoRP. ACT § 5(c) (1979).

28. The defendants may be reimbursed as a matter of right only if they are successful. See, e.g., CAL. CORP. CODE § 317(d) (West 1977 \& Supp. 1982); N.Y. BUS. CORP. LAW § 724(a) (McKinney 1963); MODEL BusiNess CORP. ACT \& 5 (c) (1979). Nevertheless, statutes often permit indemnification if there is a successful defense "or otherwise." See, e.g., DEL. CODE ANN. tit. 8 § 145(c) (1975); see also Merritt-Chapman \& Scott Corp. v. Wolfson, 321 A.2d 138 (Del. Super. Ct. 1974) (construing section 145(c) to provide indemnification after any disposition short of a criminal conviction). Under contemporary, permissive indemnification statutes, a corporation may also reimburse unsuccessfnl derivative suit defendants if it has a special bylaw that permits indemnification of fiduciaries. See, e.g., DEL. Code ANN. tit. 8 \& 145(f) (1975). Many statutes also allow the corporation to reimburse the defendants under an insurance policy. See, e.g., CAL. CORP. Code § 317(i) (West 1977 \& Supp. 1982); Del. Code ANN. tit. 8 \& 145(g) (1975); Model Business CORP. ACT $\$ 5(\mathrm{~g})$ (1971).

These statutes do little, however, to alleviate the initial uncertainty as to who will bear the cost of the defendants' hitigation expenses. Indemnification as a natter of right may depend on the outcoine of the litigation, which may be highly uncertain, especially at the pretrial motion stage. Even if the bylaws authorize indemnification of unsuccessful defendants, payment may be contingent on a finding that they were acting in the corporate interest, see, e.g., Weisner v. Air Express Int'1. Corp., 583 F.2d 579 (2d Cir. 1978), and the probability of snch a finding is often uncertain at the outset of a trial. Furthermore, courts have struck down bylaw indemnification provisions enactcd by the defendants for their own protection, see Teren v. Howard, 322 F.2d 949 (9th Cir. 1963); Essential Enters. Corp. v. Dorsey Corp., 40 Del. Cl. 343, 182 A.2d 647 (1962), although disinterested shareholder approval may remove the taint of self-imterest, see Money v. Willys-Overland Motors, 204 F.2d 888 (3d Cir. 1953); Koster v. Warren, 176 F. Supp. 459 (N.D. Cal. 1959), affd, 297 F.2d 418 (9th Cir. 1961); Sinon v. Socony-Vacuum Oil Co., 179 Misc. 202, 38 N.Y.S.2d 270 (N.Y. Sup. Ct. 1942), affd mem., 267 A.D. 890,47 N.Y.S.2d 589 (1944); cf. Lewis v. Anderson, [1981-1982 Transfer Binder] FED. SEC. L. REP. (CCH) \ 98,455 at 92,682 (C.D. Cal. 1981) (stockholder ratification of defendant-directors' conduct justifies deference to special litigation committee recommendation that suit be terminated). 
ommendation would address all these issues and would also discuss an array of additional considerations not wholly germane to the suit's merits. The bases for the committee's recommendation customarily include an evaluation of the suit's expected net gain or loss to the corporation, which takes into account any diversion of employee time, sapping of employee morale, unfavorable impact on the firm's reputation, and remedial steps taken since the commencement of the suit.

Because the corporation is the presumed beneficiary of a derivative suit, the court's decision whether to termmate or to continue the suit should take imto account the suit's total impact on the corporation. ${ }^{29}$ In making this assessment, the court ought to consider the directors' opimion of the suit's impact. Although the demand requirement allows the board to weigh the net benefit of the suit to the corporation and to make its litigation decision accordingly, the court sometimes excuses the demand requirement. ${ }^{30}$ In sucl cases, pretrial motions are a poor substitute for the review of the suit's merits that a board undertakes in response to a plaintiff's formal demand because pretrial motions are neither designed nor imtended to present issues of fact. Neither the motion for summary judgment nor the motion to dismiss allows the court to consider the net economic impact of the suit's contimuance. The motions also preclude any consideration of the problematic factual issues that surround most derivative suit allegations because neither motion can succeed on a bare showing that the suit is, more likely than not, without merit. The motions permit dismissal of the derivative action only on a clear showing that the charges are baseless. Recourse to pretrial motions after the demand requirement has been excused removes the board's factual input from the court's deliberations on whether the suit ought to proceed, and places an unwarranted gag on the corporate voice. By contrast, the special litigation committee has a procedural posture within the structure of the suit that allows it to interject factual considerations into its recommendation.

Courts rationalize the deference they afford plaintiffs who have escaped the demand requirement in a curious fashion: they assume that a plamtiff's exemption from the demand requirement establislies to

29. As the ALI reporter for the current derivative suit proposals correctly points out, however, it is an easy matter for the corporation to posit busmess-related losses that will supposcdly accrue to the continuance of the suit, because the corporation need not provide sufficient substantive details to assure that these losses in fact excecd the expected gains. See Corporate GoverNANCE, supra note 21 , commentary at 329 . Therefore, courts should closely scrutinize such costbenefit analyses.

30. See Lewis v. Curtis, 671 F.2d 779 (3d Cir. 1982), cert. denied, 51 U.S.L.W. 3758 (U.S. Oct. $5,1982)$. 
some extent the legitimacy of his claims. ${ }^{31}$ This logic is hardly compelling. The demand requirement is excused if the complaint's as yet unproven factual allegations implicate a majority of the board, making it unlikely that the directors can impartially judge the suit's merits. ${ }^{32}$ But an acknowledgment of the implications of the plaintiff's allegations is not a determination that those allegations are true. If the corporation that seeks to terminate a derivative suit were limited to the use of pretrial motions after the court excused the demand requirement, the limitations inherent in those procedural devices would bar the introduction of important factual considerations, and the court's deference to the plaintiff's pleadings would be tantamount to an a priori conclusion that the suit serves the corporate interest. Through the recommendation of the special litigation committee, however, the corporation is able to speak on its own behalf, and, under the proper standard of review, the court is able to give due deference to the plaintiffs allegations.

\section{Out-of-Court Settlements.}

Rather than press for a pretrial motion, the corporation may take a more expeditious route to rid itself of a troublesome derivative suit and enter into an out-of-court settlement with the defendants. The leading case of Wolf v. Barkes ${ }^{33}$ securely established the corporation's power to procure involuntary dismissal of derivative suits. ${ }^{34}$ In Wolf, the Court of Appeals for the Second Circuit held that rule 23(c) of the Federal Rules of Civil Procedure (the predecessor to rule 23.1), which conditions the disimissal or compromise of a class action on court approval and notice to the plaintiff class, does not apply to the corporation's release of the defendant. ${ }^{35}$ Judge Friendly reasoned that the primary purpose of the rule was to prevent a secret settlement in which the plaintiff and his attorney receive a clandestine payment from the de-

31. Compare Zapata Corp. v. Maldonado, 430 A.2d 779, 787 (Del. 1981) with Stein v. Bailey, 531 F. Supp. 684, 692 (S.D.N.Y. 1982). Automatic deference to the plaintiff when the demand requirement is excused is analogous to the automatic deference accorded the board of directors when a demand is made and rejected. The latter is based on a misapplication of the busmess judgment rule. See infra text accompanying notes 49-50.

32. Lewis v. Curtis, 671 F.2d at 799.

33. 348 F.2d 994 (2d Cir.), cert. denied, 382 U.S. 941 (1965).

34. The derivative suit plaintiff in Wolf alleged violations of the federal proxy rules, waste of assets, and the creation of wrongful stock option and compensation agreements by directors and officers of Curtis Publishing Company. The court excused the demand requirement based on the directors' alleged misconduct. Two of the defendants initiated actions against the corporation for its refusal to honor stock optious that were part of their employment contracts, 348 F.2d at 995 n.l, and this may have provoked the corporation's subsequent attempt to reach an out-of-court settlement with four of the defendants.

35. Id. at 997 . 
fendant and the corporation receives nothing; therefore, when the corporation initiates the settlement, the rule does not apply. In Judge Friendly's opinion, when the corporation undertakes a settlement, any abuse is likely to be visible to the plaimtiff shareholder, who may later charge the engineers of an improper settlement with fraud or waste of assets. ${ }^{36}$ Judge Friendly premised his analysis in Wolf on the firm belief that the corporation should have control of the corporate cause of action, even if it is brought as a derivative suit. ${ }^{37}$

Nevertheless, the court in Wolf recognized that the corporation's decision to terminate a derivative action against its officers and directors by releasing them from liability is subject to a substantial risk of structural bias: "some suspicion may attach to a settlement nade by a board of directors that has shown no inclination to collect corporate claims until its hand is forced by the start of a derivative suit." 38 The court also left open the possibility that a corporation could be enjoined from entering imto a settlement if the defendant contmued to dominate the corporation during the settlement negotiations and the plaintiff could show that there were iniproper dealings. ${ }^{39}$

\section{The Next Step-Special Litigation Committees.}

The special litigation committee is the natural progeny of the type of out-of-court settlement exemplified in Wolf. Dismissal on the recommendation of a special litigation committee and dismissal as a result of an out-of-court settlement both allow the corporation to terminate a derivative suit without being subject to the plaintiff review procedures of rule 23.1; disunissal im eacli mstance is involuntary. ${ }^{40}$ Both procedures actively involve the corporation's board in deciding whether the defendant officers or directors ought to be sued; thus, they both entail the risk that the directors' structural bias will corrupt their judgment. To prevent directors implicated in the suit from securing its termination, imdependent directors advised by experienced outside counsel sometimes represent the corporation in settlement negotiations, ${ }^{41}$ and

36. Id. at $996-97$.

37. See id. at 997.

38. Id. at 997.

39. Id. at 998 .

40. See Abbey v. Control Data Corp., 603 F.2d 724, 728 n.5 (8th Cir. 1979), cert. denied, 444 U.S. 1071 (1980). Compare Denicke v. Anglo Cal. Nat'l Bank, 141 F.2d 285 (9th Cir.), cert. denied, 323 U.S. 739 (1944) with Birnbaunt v. Birrell, 17 F.R.D. 409, $411-12$ (S.D.N.Y. 1955) (requiring court approval of settlentents by a board conceded to be independent of the derivative suit defendants).

41. See Kahn v. Kaskel, 367 F. Supp. 784, 786-87 (S.D.N.Y. 1973); Adler v. Brooks, 375 S.W.2d 544 (Tex. Civ. App. 1964). 
the same safeguards are now characteristic features of the special litigation committee. In short, the special litigation committee can be viewed as a highly systematized means of implementing the holding of Wolf.

There is, however, one distmction between the action of a special litigation committee and the broad mandate to settle suits that Wolf gives the corporation. At least thus far, special litigation committees have not executed an out-of-court settlement with the defendants, as Wolf implies that they might. ${ }^{42}$ The committees have confined themselves to instructing counsel to present the committee report to the court and to move for dismissal. This self-restraint has potential longrange benefits for the directors: any judicial determination that the committee was independent and acted in good faith, and any other matter adjudicated in the court's response to the committee's recoinmendation, can be raised defensively in a collateral attack on the committee's actions. The engineers of an out-of-court settlement have no similar ammunition with which to ward off a subsequent attack on their recommendation.

Wolf precludes any argument that the special litigation committee is an impermissible aberration in the developinent of derivative suit hitigation. Beyond question, Wolf legitimized the power of corporations to cause the dismissal of derivative suits over the plaintiff's protests. In fact, a review of Wolf and the few reported instances in which corporations have availed themselves of its precedential value to secure an out-of-court settlement ${ }^{43}$ suggests that the special litigation committee has been accorded less leeway than the corporation is granted under Wolf. For example, Wolf can be read to imply that any challenge to an out-of-court settlement must occur through a separate derivative suit for fraud or waste. If this were true, the court in the initial suit would be reduced to being an uncritical acceptor of the settlement.

Of course, this is too stringent a reading of Wolf. ${ }^{44}$ In Wolf, Judge Friendly simply suggests that a subsequent derivative suit for fraud or

42. See 348 F.2d at $997-98$.

43. Denicke, 141 F.2d at 288; Kahn, 367 F. Supp. at 786-87; Birnbaum, 17 F.R.D. at 411-12; Adler, 375 S.W.2d at 547.

44. The sole issue before the court in Wolf was whether the proposed settlennent was subject to the notice and hearing requirements of rule 23.1; there was no allegation that the settleinent was improper in any respect. Nothing in the Wolf opinion limits the court's power to enjoin the consummation of an out-of-court settlement when there is evidence of impropriety; to the contrary, Judge Friendly suggests that this would be an appropriate remedy. See 348 F.2d at 998 . Power to enjoin a settlement implies power to review a settlement, and this type of review was already in practice when Wolf was decided. See, e.g., National Bankers Life Ins. Co. v. Adler, 324 S.W.2d 35 (Tex. Civ. App. 1959). 
waste is one way to challenge an out-of-court settlement. Furthermore, this method of review is equivalent to a retrospective application of the busmess judgment rule, which is the standard that most courts use im their review of a special litigation committee's recommendation. ${ }^{45}$ Wolf's allocation of the burden of proof to those attacking the out-ofcourt settlement ${ }^{46}$ is consistent with the busmess judgment rule, and for this reason Wolf parallels numerous special litigation committee cases. ${ }^{47}$ Settlement cases such as $W o l f$ and special litigation committee cases are also similar in another way: a board that decides to settle a derivative suit and a committee that recommends that a suit be terminated are both susceptible to structural bias, which calls into question their presumed propriety and independence. 48

Despite these many similarities, the special litigation committee gives the directors' decision to terminate a derivative suit an appearance of legitimacy that is impossible in an out-of-court settlement. The very expression "out-of-court settlement" in the context of a derivative suit against insiders is pejorative, but as ineinbers of the special litigation committee, the directors presume to give a disinterested opinion of the suit's impact on the corporation. The court then decides whether dismissal is warranted, and this judicial imprimatur gives the directors' decision a more detached appearance than if they were to seal a coinpact with the defendants in an out-of-court settlement. In order to be significant, however, the court's approval of the special litigation committee's recommendation must be based on a meaningful review of the committee's work.

\section{The Appropriate Standard of Review: From AUERBACH TO $Z_{A P A T A}$}

The commercial considerations that justify the overwhelming deference courts accord director decisions in normal commercial transactions do not justify the same deference when a special litigation committee recommends dismissal or when the full board of directors rejects a demand for suit. ${ }^{49}$ The court's rejection of the recommendation nullifies its causal inipact on the corporation, and committee mem-

\footnotetext{
45. See infra text accompanying note 51 .

46. 348 F.2d 994.

47. See id. at 996.

48. For nearly parallel views on their respective subjects, compare Comment, Compromise of Derivative Claims by a Corporation Without Court Approval, 52 VA. L. Rev. 342, $345-48$ (1966) with Note, Special Litigation Committees: An Unwelcome Solution to Shareholder Demands, 1981 U. ILL. L. REV. 485.

49. Joy v. North, [Current] FED. Soc. L. REP. (CCH) I 98,860 at 94,439 (2d Cir. 1982); Brudney, The Independent Director-Heavenly City or Potemkin Village?, 95 HARv. L. Rev. 597, 630-31
} 
bers cannot be held liable for their recommendation if it has no adverse effects. Therefore, the court need not temper its scrutiny of the committee's recommendation in order to protect the directors from liability for having reached an improper result. Furthermore, because the committee's recommendation that a suit be dismissed is not, strictly speaking, within the directors' busmess expertise, the court's usual extreme deference to board decisions in commercial transactions need not extend to the committee's recommendation. For these reasons, the court ought to take an active role im evaluating the committee's recommendation (just as it is expected to scrutinize derivate suit settlements ${ }^{50}$ ) in order to protect its procedures from abuse by unjustified recommendations of dismissal and to offset the serious threat of structural bias.

Unfortunately, most courts adhere uncritically to the business judgment rule when they review the recommendation of a special litigation committee. The quintessential expression of the doctrime of deference appears in Auerbach v. Bennett, ${ }^{51}$ which holds that it is mappropriate for a court to evaluate a committee's weighing of the legal, ethical, commercial, public relations, or fiscal grounds that support the committee's recommendation that a derivative suit be dismissed. ${ }^{52}$ Under the business judgment rule, these considerations are exclusively within the directors' domain. Therefore, the Auerbach court confined its examination to the areas that have traditionally reinained open to inquiry under the business judgment rule: the directors' imdependence and good faith. ${ }^{53}$ Although these areas of imquiry include challenges to the adequacy and appropriateness of the committee's procedures, ${ }^{54}$ the substantive bases for the committee's recommendation remain beyond judicial review, shielded by the busmess judgment rule's mandate of deference.

By protecting the special litigation committee, the court in Auerbach correctly makes available to the corporation the most effective means of expressing its views on the costs and benefits of the continuance of a derivative suit. To refuse to hear the corporation's views just because the board is implicated by the plaintiff's allegations would be to prejudge the outcome of the case and its ultimate benefit to the corporation. Nevertheless, Auerbach's view that director decisions are fungible, whether the decision is a committee's recommendation that a

(1982); Coffee \& Schwartz, The Survival of the Derivative Suit: An Evaluation and a Proposal for Legislative Reform, 81 CoLuM. L. REv. 261, 280-83 (1981).

50. See infra note 92.

51. 47 N.Y.2d 619, 393 N.E.2d 994, 419 N.Y.S.2d 209 (1979).

52. Id. at 633,393 N.E.2d at 1002,419 N.Y.S.2d at 928.

53. Id. at $623-24,393$ N.E.2d at 996,419 N.Y.S.2d at 922.

54. See id. at 623-24, 393 N.E.2d at 996, 419 N.Y.S.2d at 922. 
suit be dismissed or a board's decision to taise the price of the nickel candy bar, is incorrect. Auerbach is too subservient to the special hitigation committee and extends undue deference to committee recommendations. Several considerations warrant stricter judicial scrutiny when a board responds to a demand for suit or when a special litigation committee makes its recommendation than when a board inakes a traditional managerial decision. ${ }^{55}$ The current position of the Delaware Supreme Court and the proposal now under consideration by the ALI present alternatives to the Auerbach approach. Unfortunately, each misdirects the focus of judicial review.

\section{A. The Talking Horse: Zapata Corporation v. Maldonado.}

The novel approach of the Delaware Supreme Court in Zapata Corp. v. Maldonados6 has caused a good deal of excitement among commentators who advocate heightened judicial scrutmy as a restraint on the special litigation committee. ${ }^{57}$ Like words spoken by the talking horse on television, however, Zapata is cause for excitement because of its source, not its substance.

The chancery court in Zapata ${ }^{58}$ held that because the business judgment rule is a "shield and not a sword," it can only protect direc-

55. See supra text accompanying notes $49-50$.

56. 430 A.2d 779 (Del. 1981).

57. See, e.g., Coffee \& Schwartz, supra note 49, at 327-30; DeMott, Defending the Quiet Life: The Role of Special Counsel in Director Terminations of Derivative Suits, 56 NOTRE DAME LAW. 850, 853-54 (1981); Stemberg, Maldonado in Delaware: Special Litigation Committees-An Unsafe Haven, 9 SEC. REG. L.J. 381 (1982); Comment, Off the Bench and into the Boardroom: Judicial Business Judgment after Zapata, 70 GEO. L.J. 1025 (1982); Comment, Zapata Corp. v. Maldonado: Restricting the Power of Special Litigation Committees to Terminate Derivative Suits, 68 VA. L. REv. 1197 (1982); Note, Business Judgment Dismissal of Shareholder Derivative Suits by Board Litigation Committees: An Expanded Role for the Courts, 35 VAND. L. REv. 235 (1982); Comment, Directors' Business Judgment in Terminating Derivative Suts Subject to Judicial Review, 59 WASH. U.L.Q. 1425 (1982); ff. Block \& Prussin, The Business Judgment Rule and Shareholder Derivative Actions: Viva Zapata, 37 Bus. LAw. 27, 28, 38-58 (1981); Fischel, The "Race to the Bottom" Revisited: Reflections on Recent Developments in Delaware's Corporation Law, 76 Nw. U.L. REv. 913, 935-41 (1982).

58. Maldonado v. Flynn, 413 A.2d 1251 (Del. Ch. 1980).

In 1975 Maldonado filed suit in the Delaware Court of Chancery against all ten directors of Zapata Corporation, alleging that in 1974 the board accelerated the exercise date of certain stock options in order to reduce the personal tax liability of many of the directors, who held the options. The acceleration also allegedly lessened the tax deduction available to the corporation. Maldonado later commenced an action under the federal securities laws agamst nime of the ten directors, alleging that improper disclosures were made in connection with the acceleration. The counplaint in the federal suit was dismissed, but the circuit court reversed im part and remanded the case. See Maldonado v. Flynn, 448 F. Supp. 1032 (S.D.N.Y. 1978), affd in part, rev'd in part \& remanded, 597 F.2d 789 (2d Cir. 1979). In 1979, when four of the defendant-directors were no longer on Zapata's board, the board established a special hitigation committee and appointed to the committee two directors not involved in the stock option inodifications. Three months after its creation, the committee recommended that the derivative suit was not in the corporation's best interest and 
tors' decisions from subsequent stockholder attack and cannot operate affirmatively to validate the decision of a special litigation committee (or of the whole board) to request dismissal of a derivative suit. ${ }^{59}$ The Delaware Supreme Court reversed 60 because the Vice Chancellor's inflexible rule gave the plaintiff too inuch control over the corporation's litigation decisions. Reviewing the broad language of the Delaware General Corporation Law that governs the board's power and the amount of power that the board may delegate to its committees, ${ }^{61}$ the court held that a properly constituted committee could have power coequal to that of an independent board of directors. ${ }^{62}$

Zapata recognized that in such circumstances the court's review of the committee's recommendation must be delicately balanced.63 A standard of review strongly deferential to the special litigation committee's prerogatives could mortally wound the derivative suit. Conversely, too stringent a standard could plague corporations with burdensome suits. By seeking a middle course, the court dennonstrated a sensitivity to the abusive potential of structural bias rarely seen in special litigation committee cases:

Moreover, notwithstanding our conviction that Delaware law entrusts the corporate power to a properly authorized committee, we must be mindful that directors are passing judgment on fellow directors in the same corporation and fellow directors, in this instance, who designated them to serve both as directors and coinmittee members. The question naturally arises whether a "there but for the grace of God go I" empathy might not play a role. And the further question arises whether inquiry as to independence, good faith and reasonable investigation is sufficient safeguard against abuse, perhaps subconscious abuse. ${ }^{64}$

Unfortunately, although the court held that the business judgment rule is an inappropriate standard of review, the two-tiered analysis it offered in its place provides only an illusory improvement.

instructed the corporation's counsel to move for dismissal of both the state and the federal suits. The federal court granted the motion, see Maldonado v. Flynn, 485 F. Supp. 274 (S.D.N.Y. 1980), but the state court denicd it, see Maldonado v. Flynn, 413 A.2d 1251 (Del. Ch. 1980). The Court of Appeals for the Second Circuit stayed the appeal from the district court's decision pending the Delaware Supreme Court's resolution of the appeal from the Court of Chancery. See Maldonado v. Flynn, 671 F.2d 729, 731 (2d Cir. 1982).

59. 413 A.2d at $1256-57$.

60. 430 A.2d at 779 .

61. Id. at 785 .

62. Id. at 786 .

63. Id. at $786-87$.

64. Id. at 787 . 


\section{B. The First Level of Analysis under Zapata: Independence, Good Faith, and Factual Support.}

The Delaware court in Zapata directs the lower courts to first review the committee's independence, good faith, and the bases for its recommendation. ${ }^{65}$ The court likens the review procedure to a motion for summary judgment ${ }^{66}$ because the motion is not granted if there are genume factual issues; however, the court also intimates that the review may mclude the resolution of factual conflicts through a mini-trial.67 To facilitate the court's review of the committee's actions, Zapata requires the corporation to submit a record of its investigation, imcluding a report of its findings and recommendations. Although Zapata directs the court to consider the "bases" for a committee's recommendation, it does not define the term. The committee's record of its investigation, together with its report, may perhaps form the "bases" of the committee's decision. ${ }^{68}$ In one paragraph, however, the court uses "bases" interchangeably with "reasonable imvestigation." 69 This suggests that the bases for a recommendation are the procedures that produced it rather than the specific grounds and findings that support it. The Zapata court apparently envisioned its approach as a compromise between the automatic deference of the busmess judgment rule and total skepticism. Because the court's use of the term "bases" is ambiguous, however, it is questionable whether scrutimy of the committee's recommendation under Zapata is significantly different from scrutimy under Auerbach.

1. The Burden of Proof. Zapata responds to the abusive potential of structural bias by placing on the corporation the burden of estabhishing the committee's independence and good faith, and the reasonableness of its investigation. Before Zapata, courts required the plaimtiff to proye that the committee lacked good faith or independence, ${ }^{70}$ but the lesson to be drawn from those cases is that Delaware's reallocation of the burden of proof to the corporation is not likely to change the end result, at least insofar as good faith and independence are concerned. ${ }^{71}$ In all but one case, ${ }^{72}$ the committee refuted the plamtiff's challenge to its imdependence simply by showing that a majority of

65. Id. at 788-89.

66. Id.

67. $I d$. at $788 \mathrm{n} .15$.

68. $I d$. at 788 .

69. $I d$. at $788-89$.

70. See infra note 73 (cases cited).

71. The shift in the burden of proof may be significant, however, with respect to Zapata's requirement that the committee have a reasonable basis for its recommendation, especially if this requirement means that the committee must prove that the suit will result in a net loss to the corporation. See infra notes $75-90$ and accompanying text. This shift in the burden of proof is 
the committee members were not defendants in the derivative suit. ${ }^{73}$ Although the good faith requirement is in theory sufficiently broad to be the poimt of departure for a searching inquiry into the committee's performance, to date it has failed to have any substantive impact in special litigation committee cases. In examining the committee's performance under the good faith standard, courts have been satisfied if the investigation appears systematic and diligent; they have not considered whether the information on which the committee based its decision actually justified the result. ${ }^{74}$

also justified by efficiency considerations: the committee is in a better position than the plaintiff to produce evidence in support of the issue in dispute.

When the net-loss issue arises in suits involving an alleged violation of criminal statutes, however, the derivative suit plaintiff has the burden of proving that the illegal act caused a net loss to the corporation. See Siles v. Elfred, 149 N.Y.L.J., Feb. 20, 1963, at 14, col. 6 (N.Y. Sup. Ct. 1963).

72. Swenson v. Thibaut, 39 N.C. App. 77,250 S.E. $2 d 279$ (1978), is the only case to date in which the court has found that the committee lacked the requisite independence. This finding is attributable to the fact situation of the case rather than to the court's penetrating review of the committce's performance. In the same meeting at which it established the special litigation committee, the full board, imcluding those members who would later serve on the committee, resolved that the derivative suit was not in the corporation's best interests. Id. at 81,250 S.E.2d at 287 . Ironically, it was the court in Swenson, not the plaintiff, that first questioned this suspect procedure. The result in Swenson is analogous to the excnsal of the demand requirement when the directors liave already manifested their opposition to the suit. See, e.g., Nussbacher v. Continental Ill. Nat'l Bank \& Trust Co., 518 F.2d 873, 878 (7th Cir. 1975), cert. denied, 424 U.S. 928 (1976). The court in Joy v. North, [Current] FED. SEC. L. REP. (CCH) I] 98,860 (2d Cir. 1982) could have used the committee members' prior refusal of the plaintif's demand as a ground to discredit the committee's recommendation that the suit be dismissed, but it did not rely on that refusal in denying the recommendation. Id. at 94,435 n.3.

73. See, e.g., Games v. Haughton, 645 F.2d 761 (9th Cir. 1981), cert. denied, 102 S. Ct. 1006 (1982); Abbey v. Control Data Corp., 603 F.2d 724, 727 (8th Cir. 1979), cert. denied, 444 U.S. 1017 (1979); Cramer v. GTE, 582 F.2d 259 (3d Cir.), cert. denied, 439 U.S. 1129 (1978); Rosengarten v. ITT Corp., 466 F. Supp. 817 (S.D.N.Y. 1979).

In Lewis v. Anderson, 615 F.2d 778 (9th Cir. 1979), cert. denied, 449 U.S. 869 (1980), the court recognized the committee's independence even though one of its three nembers was a named defendant in the derivative action; that director, however, had not benefited directly from the challenged conduct. Id . at 780 . Therefore, although the Ninth Circuit's finding that the committee in Lewis was independent is unusually permissive, it is consistent with the demand requirement cases holding that a director named as a defendant may still be capable of giving an unbiased opmion of the derivative suit's merits. See In re Kauffman Mut. Fund Actions, 479 F.2d 257 (1st Cir. 1973); Barr v. Wackman, 36 N.Y.2d 371, 329 N.E.2d 180, 368 N.Y.S.2d 497 (N.Y. 1975).

It is arguable that the Lewis court should have distinguished the (higher) level of director interest necessary to excuse a demand from the (lower) level of interest that justifies disregarding a board's decision not to sue. See supra note 8. See generally DeMott, supra note 57 at 859-60. Even if this distinction is correct, however, it may well be that the level of director interest in Lewis was low enough to have passed even this inore critical test.

74. See, e.g., Rosengarten v. ITT Corp., 466 F. Supp. 817 (S.D.N.Y. 1979); Auerbacl v. Bennett, 47 N.Y.2d 619, 393 N.E.2d 994, 419 N.Y.S.2d 920 (N.Y. 1979). 
Because Zapata does not make the burdens of proving mdependence and good faith heavier, shifting these burdens of proof to the corporation is unlikely to result im any perceptible weakening of the special litigation committee's prerogatives. The unusual sensitivity of the Delaware Supreme Court to the threat of structural bias may in time cause a significant change in the definition of director independence. Structural bias, however, is unlikely to be detected if the definition of independence focuses solely on the director's involvement with the defendant or with the alleged misconduct. Independence in the sense of freedoin from structural bias concerns a director's attitude, not his more observable relationships to the defendant or to the questionable conduct. This is not to suggest that a strict definition of director mdependence is unimportant; it is, lowever, an insufficient safeguard agamst structural bias.

2. The Bases of the Committee's Recommendation. If the first level of analysis under Zapata is to impose any significant restraimt on the prerogatives of the special litigation committee and subject the committee to closer scrutimy, it must come from the final requirement that there be a reasonable basis for the committee's recommendation. Although the meaning of this requirement is not entirely clear, ${ }^{75}$ there is ample reason to conclude that it demands something more than a general statement of the grounds for the committee's recommendation.

Special litigation committees generally identify the grounds for their recommendations, but only infrequently offer facts or findings to support these grounds. The grounds for a committee's recommendation that a suit be dismissed have ranged from doubts about the suit's merits to humanitarian concerns for the defendant and his family. ${ }^{76}$ To be acceptable, however, the grounds ought to support the conclusion that the derivative suit will cost the corporation more than it will benefit it. ${ }^{77}$ The court should ignore the committee's recommendation if it rehes on any other basis for dismissing the suit. This hinitation on the acceptable grounds for the committee's recounmendation is intuitively appealing. It is also analogous to the requirements imposed by the courts im other areas of derivative suit litigation: before a corporation

75. See supra notes $65-70$ and accompanying text.

76. See, e.g., Maher v. Zapata Corp., 490 F. Supp. 348, 350-51 (S.D. Tex. 1980) (committee offered twelve grounds for its recommendation).

77. The proposal currently before the ALI places on the defendants the burden of proving that the fiduciary's breach or unlawful act yielded a net gam to the corporation. A court is to "disregard any such gains or offsets if it finds that their recognition would frustrate an authoritatively established public policy." CORPORATE GOVERNANCE supra note $21, \$ 7.06(b)$. 
may indemnify or defend the defendants, or settle the suit, it must demonstrate that the benefits of such action would outweigh its costs. ${ }^{78}$

If Zapata requires only that the committee establish a reasonable basis for its recommendation and uses the phrase "reasonable basis" as it is commonly understood in conventional apphications of the business judgment rule, Zapata does little to raise the court's standard of review. Under the conventional reasonable basis test, directors may choose with impunity from mutually exclusive alternative courses of action as long as they have satisfactory factual or authoritative support for the course they choose to take. ${ }^{79}$ The legacy of this standard is a series of

78. A leading indeinnification case illustrates the significance of a cost-benefit analysis in determining whether indemnification is appropriate. In Koster v. Warren, 176 F. Supp. 459 (N.D. Cal. 1959), affd, 297 F.2d 418 (9th Cir. 1961), a stockholder of Safeway Stores challenged the board's indemnification of its former officers for the expenses they incurred in their defense of a criminal antitrust action. Safeway desired to settle the action to avoid the collateral estoppel effects of an antitrust judgment. Id. at 423. The government conditioned settlement on a plea of no contest by the corporation and all named defendants, but the individual defendants agreed to so plead only if they would be fully indemnified for their litigation expenses. Safeway agreed, and all parties entered a plea of nolo contendere. $I d$. at 423 . The court in the subsequent derivative suit held indemnification appropriate under these facts because the benefit of settlement to the corporation outweighed the cost of indemnification. Id. at 423-24. The court did not undertake a detailed review of the amount of benefit that the arrangement produced, quite likely because it was clear that the value of avoiding the precedential effects of a government antitrust judgment would exceed the $\$ 71,000$ that the officers received for their cooperation. See also Wisener v. Air Express Int'l Corp., 583 F.2d 579 (2d Cir. 1977).

A cost-benefit analysis also plays a role in determining whether a corporation may defend a derivative suit on the merits. Under the prevalent view, the corporation may defend on the merits if the derivative suit seeks to change the corporation's inanner of doing business but does not allege that the directors acted out of self-interest. See Otis \& Co. v. Penn. R.R., 57 F. Supp. 680 (E.D. Pa. 1944), aff d, 155 F.2d 522 (3d Cir. 1946). This is equivalent to a requirement that the directors conclude that the cost of the suit would clearly outweigh its potential benefit to the corporation. See, e.g., Swanson v. Traer, 230 F.2d 228, 234 (7th Cir. 1956); Messing v. F.D.I., Inc., 439 F. Supp. 776, 782 (D.N.J. 1977). See generally Note, Defenses in Shareholder Derivative Suits-Who May Raise Them, 66 HARv. L. REv. 342 (1952). But see Swenson v. Thibaut, 39 N.C. App. 77, 250 S.E.2d 279 (1978).

Finally, inany courts approve settlements of derivative suits because they are concerned that continuation of the suit would subject the corporation to costs in excess of its expected benefits. See, e.g., Shlensky v. Dorsey, 574 F.2d 131, 147 (3d Cir. 1978); Newman v. Stein, 464 F.2d 689, 692 (2d Cir.), cert. denied, 409 U.S. 1039 (1972); Schreiber v. Jacobs, 128 F. Supp. 44 (E.D. Mich. 1955). In a few cases, courts have approved settlement even though the terms of the settlement were of questionable value because they seriously doubted that the suits had merit. In sucl cases, the cost of continuing the litigation is always excessive. For example, in Lewis v. Anderson, 81 F.R.D. 436, 439 (S.D.N.Y. 1979), the court approved a settlement in which defendants agreed to abide by a company policy to which they were already subject, and in Cannon $\bar{v}$ - Texas Gulf Sulphur Co., 55 F.R.D. 308, 317 (S.D.N.Y. 1972), the primary benefit to the corporation of settling a derivative suit was the defendants' agreement not to seek indemnification for their litigation costs. In both Lewis and Cannon, however, the corporation was extreinely unlikely to prevail on the merits.

79. For example, in Elfenbein v. Anerican Financial Corp., 487 F. Supp. 619 (S.D.N.Y. 1980), the court held that the directors of a parent corporation had a reasonable basis for their exercise of warrants in a subsidiary corporation because they relied on counsel's opinion that the exercise presented no perils under the tax laws even though two other experts disagreed. The 
cases that evidence an uncritical acceptance of the directors' choice; the courts fail to consider the relative support for the directors' alternative courses of action. The conventional reasonable basis standard could dissuade a court from undertaking a comprehensive inquiry into the special hitigation committee's report and into the record produced at a hearing to decide whether the support for the committee's recommendation is compelling. Under the conventional test, the court merely reviews the record to determine whether the recommendation is a plausible interpretation of the facts and the law.

Abramowitz v. Posner ${ }^{80}$ illustrates the use of the reasonable basis test under the busmess judginent rule in cases prior to Zapata. In response to SEC charges that they had misappropriated corporate funds, Posner and other directors entered into a consent decree that required them to reimburse $\$ 600,000$ to the corporations under their control. The decree also required the directors to establish independent audit committees to determine if further legal action by each corporation was appropriate. Subsequently, a shareholder imitiated a derivative action to recover additional funds that were not recouped through the consent decree.

After an extensive investigation, the audit committees recoinmended that the corporations seek reimbursement of $\$ 1,021,445$ and bring suit against the directors only if they failed to make the reimbursement. ${ }^{81}$ In rendering their opimon, the committees revealed a marked bias toward the defendants:

The amount which the audit committees have recommended should be reimbursed may not necessarily be the maximum amounts which the companies could obtaim from such officers or directors in an action naming them as defendants where the full range of judicial procedures for the ascertaining of facts would be available, or if presumptions arising from the absence of appropriate records wcre utilized to determine the amounts due. ${ }^{82}$

court in Muschel v. Western Union Corp., 310 A.2d 904, 908-09 (Del. Ch. 1973), held that the decision of an acquiring corporation's directors that a merger's terms were fair was reasonably based on a projection of the earnings of the companies as combined entities even though a projection of the imdividual companies' earnings suggested that the terms were unfair. See also Panter v. Marshall Field \& Co., 486 F. Supp. 1168, 1180, 1194 (N.D. 111. 1980), aff d, 646 F.2d 271 (7th Cir.), cert. denied, $102 \mathrm{~S}$. Ct. 658 (1981) (directors armed with opinion of counsel that bidder for control posed serious antitrust problems had reasonable basis for defensive maneuvers even though ample evidence indicatcd that antitrust issues could be resolved); Warshaw v. Calhoun, 43 Del. Ch. 148, 159, 221 A.2d 487, 494 (Sup. Ct. 1966) (alternative financing plans all deemed reasonable, choice among plans was a matter of director discretion).

80. 513 F. Supp. 120 (S.D.N.Y. 1981), affd, 672 F.2d 1025 (2d Cir. 1982).

81. Id. at 120, 123.

82. Id. at 124. 
The audit committees rationalized their generosity toward the defendants by noting that the defendants had greatly benefited the corporation during their terins as directors and by acknowledging that the corporation had enacted new policies and controls to prevent recurrence of the challenged practices. ${ }^{83}$

When the derivative suit plaintiff in Abramowitz made his required demand on the board, the board based its rejection of the demand on the audit committees' report. The district court upheld the rejection and dismissed the case without examining the bases for the audit committees' recommendation. The Delaware court decided Zapata before Abramowitz reached the Court of Appeals for the Second Circuit on appeal; however, because the demand requirement was not excused in Abramowitz as it had been in Zapata, the circuit court affirmed the district court's limited review, holding Zapata's two-level analysis mapplicable. ${ }^{84}$ The court held that the business judgment rule would apply to the board's rejection of the demand unless the plaintiff established that the board acted without good faith or lacked independence. 85

The facts before the audit committees in Abramowitz were not unequivocal; the committees might have decided that the plaintiff's complaint warranted the more complete factual investigation that a formal trial would provide or that a jury could reasonably draw damaging inferences from the facts. If it had exainined the case under Zapata's first level of analysis, the court would have required a inore fully developed report of these possibilities in place of the committees' glib recognition of the uncertainties of litigation. ${ }^{86}$ Under the conventional reasonable basis test, however, the court will not disturb the directors' decision as long as its factual support is not insubstantial, even if the court finds a strong likelihood that an alternative decision was advised. If Zapata requires this level of review, the court in Abramowitz could have reached the same result even if it had applied Zapata because there was a reasonable basis for the committees' recommendation. This reading of Zapata, however, accords the committee too much freedoin and gives the court too little authority to evaluate the committee's ability to render a detached opmion of the suit's benefits to the corporation. ${ }^{87}$

83. Id. at 123 .

84. 672 F.2d at 1032-33. The corporation in Abramowitz was a Delaware corporation. 513 F. Supp. at 121 .

85. 672 F.2d at 1033 .

86. Id.

87. Although the reasonable basis standard has been involved in several business judgment rule cases, see supra note 79 (cases cited), courts generally have contented themselves with examining the facts for fraud, oppression, or self-dealing on the part of the directors. Bishop, supra 
3. The Impact of Zapata. The Zapata court departed from the highly deferential stance taken in Auerbach because of its concern that director bias may skew the committee's recommendation; but the subtle hand of structural bias cannot be directly detected. An imquiry into the record and factual bases that support a recommendation is $\mathrm{m}$ effect a surrogate investigation of the committee's structural bias: if the facts do not support the recommendation, it is highly likely that the committee was influenced by factors other than the corporate interest. ${ }^{88}$ Where Auerbach precludes an inquiry into the factual bases of a committee's recommendation, Zapata's overriding concern with director bias should require a searching inquiry into both the facts that support the recommendation and into the net costs and benefits of the recommendation to the corporation. ${ }^{89}$

note 2, at 1099-1101. See generally Arsht, Business Judgment Rule Revisited, 8 HofSTRA L. REv. 93 (1979). Even in states whose corporate statutes prescribe a standard of reasonableness for directors' conduct, courts have limited their inquiry to the questions of good faith and independence. Compare N.Y. Bus. CoRP. LAW $\$ 717$ (McKinney Supp. 1981) with Kamin v. American Express Co., 54 A.D.2d 654, 387 N.Y.S.2d 993 (Sup. Ct. 1976). Thus, if the Delaware Supreme Court adopted the reasonable basis standard, courts would assume a more active role than they generally have in conventional business judgment rule cases. Nevertheless, this higher level of review falls short of that desirable to unearth director bias.

88. See Watts v. Des Moines Register and Tribune, 525 F. Supp. 1311 (S.D. Iowa 1981). In Watts, a committee recoinmended that a cause of action be disinissed even though its special counsel recommended litigation. The court held the matter for further consideration of the committee's reasons for departing from its counsel's advice. It remains to be seen what response a reviewing court would make under Zapata if counsel's opinion were more equivocal. For example, in Lasker v. Burks, 567 F.2d 1208, 1210 (2d Cir. 1978), rev'd, 441 U.S. 471 (1979), counsel to the special litigation committee submitted its opinion that the defendants were not liable, but substantially qualified that opimion by noting the absence of legal authority on the issue in question. Counsel further cautioned that it could not determine how such an untested issue would be resolved.

89. The adversarial proceeding envisioned by Zapata, which focuses on the record developed by the committee, has as an indispensable adjunct more expanded discovery powers for the plamtiff, who inust challenge the committee report. Under the Auerbach doctrine, the scope of discovery available to the plaintiff is limited to inatters that bear closely on the committee's good faitl and independence and does not extend to an inquiry into the cominittee's reasoning, its decisionmaking process, and the factual bases for its recommendation. See, e.g., Lewis v. Anderson, 615 F.2d 778 (9th Cir. 1979), ccrt. denied, 449 U.S. 869 (1980); Abbey v. Control Data Corp., 603 F.2d 724 (8th Cir. 1979), cert. denicd, 444 U.S. 1017 (1980); Cramer v. GTE, 582 F.2d 259 (3d Cir. 1978), cert. denied, 439 U.S. 1129 (1979); Gall v. Exxon Corp., 418 F. Supp. 508 (S.D.N.Y. 1976); Auerbach v. Bennett, 47 N.Y.2d 619, 393 N.E.2d 994, 419 N.Y.S.2d 920 (1979). As a result, the plaintiff can prevail under Auerbach only if there is irrefutable evidence of committee bias. See Sweuson v. Thibaut, 39 N.C. App. 77, 250 S.E.2d 279 (1978); see also supra note 72 (discussion of Swenson).

It inust be noted, however, that the Zapata court merely observed that the necessary discovery may be ordered. 430 A.2d at 788 . The court then cited several cases in wlich discovery was not extended to the suit's merits. Id. at 788 n.16. Tliree of the four cases citcd limit the plaintiff to deposing the committee's participants on their good faith and independence. See Galef v. Alexander, 615 F.2d 51, 56 (2d Cir. 1980); Rosengarten v. ITT, 466 F. Supp. 817, 823 (S.D.N.Y. 1979); Gall v. Exxon Corp., 418 F. Supp. 508, 520 (S.D.N.Y. 1976). Only in Maldo- 
Under this interpretation of Zapata, the adversarial review of a committee's recommendation should determine more than whether the grounds for the committee's recommendation have reasonable factual support. Courts should not be misled by the bare articulation of numerous unsupported grounds for dismissal or by grounds with only weak factual support. The proponents of the committee report should have the burden of proving that among all possible courses of action, those embodied in the committee's recommendation are most likely to serve the corporate interests. ${ }^{90}$

nado v. Flynn, 485 F. Supp. 274, 285-86 (S.D.N.Y. 1980), is there dicta, but no holding, obliquely suggesting that the plaintiff may have more extensive discovery power. In at least one case (not cited by Zapata), the court allowed discovery on the suit's unerits, but the plaintiff did not succeed in discrediting the committee's recommendation. See Genzer v. Cunningham, 498 F. Supp. 682, 697 (E.D. Mich. 1980).

In a recent decision following Zapata, the court allowed the plaintiff to depose the committee's meinbers on the objective factors underlying their decision, but the court limited the permissible scope of the inquiry to the factors that entered into the committee's decision. See Watts v. Des Moines Register and Tribune, 525 F. Supp. 1311 (S.D. Iowa 1981). The court did not permit questions concerning why the committee considered those factors and ignored others. This limited extension of the plaintiff's discovery power sliould enable the plaintiff to attack the reasonableness of the committee's report ouly if the plaintiff has also had an opportunity to engage in discovery against the corporation and the defendants on the inerits of the suit. When, as in Zapata, the derivative suit begins several years before the special hitigation committee inakes its recommendation, the plaintiff is likely to be armed with enough information about the case's merits to seriously review the factors considered by the committee. If, however, the committee makes its report soon after the initiation of the suit, the plaintiff's effort to discredit the committee may be seriously crippled if discovery is confined to those matters the committee chose to include in its inquiry.

90. There is evidence that courts can assume a less passive role by using pleadings, affidavits and "minitrials" to determine early in the litigation whether a derivative suit is worth pursuing. California's security for expense statute, CAL. CORP. CODE $\$ 800$ (c)-(e) (West 1977), for exainple, requires the corporation or the defendant to prove that the suit is not reasonably likely to benefit the corporation. See id. $\$ 800$ (c); Koster v. Warren, 297 F.2d 418 (9th Cir. 1961); Burt v. Irvine Co., 237 Cal. App. 2d 828, 47 Cal. Rptr. 392 (1965); Marble v. Latchford Glass Co., 205 Cal. App. 2d 171, 22 Cal. Rptr. 789 (1962); Thomas v. Summers Gyroscope Co., 160 Cal. App. 2d 234, 324 P.2d 893 (1958); Kaiser v. Easton, 151 Cal. App. 2d 307, 311 P.2d 108 (1957); Olson v. Basin Oil Co. of Calif., 136 Cal. App. 2d 543, 288 P.2d 952 (1955); Wood v. Gordon, 112 Cal. App. 2d 374, 246 P.2d 84 (1952). See generally Ballantine, Abuses of Shareholders Derivative Suits: How Far is California's New "Security for Expenses" Act Sound Regulation, 37 CALIF. L. REv. 399 (1949).

By contrast, courts often fail to subject proposed derivative suit settleinents to close analysis. See generally Note, The Need for Findings of Fact and Conclusions of Law in the Approval of Proposed Setllements of Shareholder Derivative Actions, Greenspan v. Bogan, 492 F.2d 375 (lst Cir. 1974), 36 OHIo ST. L.J. 163 (1975). In a recent case, the Court of Appeals for the Second Circuit offers guidance to courts exercising their own independent judgment under Zapata's second level of analysis. See Joy v. North [Current] FED. SEC. L. REP. (CCH) \ 98,860 (2d Cir. 1982). The court should dismiss the case if it finds "that the likely recoverable danages discounted by the probability of a finding of liability are less than the [direct] cost of the corporation in continuing the action." Id. at 94,442 . According to the court, direct costs include the corporation's hitigation expenses, employee time, and mandatory indemnification costs. Id. After accounting for insurance, if the recovery expected exceeds direct costs, but is insubstantial in relation to shareholder equity, the court may consider incidental costs, such as dainaged einployee inorale 
In undertaking this review there is little to guide a court other than its own independent judginent. Courts should be aware that there is often an inverse relationship between the strength of a suit's merits and the persuasiveness of other grounds that a committee inay advance in support of dismissal. As derivative suits that end in a settlement demonstrate, courts are less willing to accept grounds for settlement that are unrelated to the suit's inerits when the suit is not frivolous.91 On the other hand, if a court is satisfied that factual or legal issues pose significant obstacles to the plaintiff, it will readily approve a settlement in which the primary benefit to the corporation is simply its avoidance of undetermined future litigation costs and the disruption of its operations.92 These general observations are hardly legal talisinans for

and lost profits caused by the suit. Id. The Joy court's distinction between direct and incidental costs appears to recognize that the latter should play a role only in cases of questionable benefit to the corporation because such costs are inherently incapable of satisfactory measurement.

91. See supra note 78. For example, in In re Pittsburgh \& Lake Erie R.R., 543 F.2d 1058 (3d Cir. 1976), the primary benefit of the settlement to the corporation was avoiding the aggravation, expense, and inconvenience of the suit. See id. at 1073 n.6. The appellate court reversed the district court's approval of the settlement on the grounds that the settlement was of insufficient benefit to the corporation, id. at 1069; the court demanded a specific finding that the costs avoided by settleinent outweighed the $\$ 2,100,000$ that the corporation was required to pay. Id. It is no coincidence that the defendant virtually conceded liability in In re Pittsburgh. See id. at 1061-62. The merit of the derivative suit claim warranted the appellate court's critical review of the settlemeut's terms.

92. See supra note 78. In Shlensky v. Dorsey, 574 F.2d 131, 147 (3d Cir. 1978), the Court of Appeals for the Third Circuit reviewed the proposed settlement of eight derivative actions of dubious merit. The Shlensky court enumerated several benefits of settlement to the corporation, but eacl was of questionable value. The settlement provided full indemnification for the defendants, but the corporation's indemnification insurer agreed to pay $\$ 2,000,000$ to the corporation in return for a release fron the indemnification policy. Presumably, the $\$ 2,000,000$ was the cstimated cost of indemnification, but this payment benefited the corporation only because the settlement required indemnification, which nany settlements do not. The court considered the payment a benefit because there was some question whether the insurer was legally bound to honor its contract with the corporation, $574 \mathrm{~F} .2 \mathrm{~d}$ at $148 \mathrm{n} .1 \mathrm{l}$; however, it is unlikcly that the corporation would have agreed to the indemnity provision in the settlement if its insurer had not agreed to pay. Similarly, the settlement allegedly benefited the corporation by its cancellation of the defendants' stock options, valued at more than $\$ 850,000$. Id. at 148. Because it is uncertain that options will be exercised, however, sone courts consider this type of gain illusory. See, e.g., Fricke v. Daylin, Inc., 66 F.R.D. 90 (E.D.N.Y. 1975). The settlement in Shlensky also included the return of $\$ 620,000$ in earned executive incentive compensation. The corporation's board had returned the compensation two inonths earlier for reasous unrelated to the derivative suit, however, so the benefit to the corporation of the settlement was actually the defendants' release of their potcntial claim against the corporation for its earher cancellation of their incentive compensation. $574 \mathrm{F.2d}$ at 146. Nevertheless, the $\$ 607,000$ attorney's fee that the corporation paid under the tcrms of the settlement, see id. at 150,152 , probably outweighed the benefit of the release. Finally, the Shlensky court noted that settlement would avoid the cost, inconvenience, and danuage to the corporate reputation that continued litigation would entail, but the court did not value this benefit monetarily. The total expected benefit of settlement to the corporation was set at $\$ 3,500,000$, id. at $145-46$, and the total value of the spurious benefits described above is $\$ 3,470,000$. Thus the major benefit of this settlement probably was the avoidance of continued litigation and a cost savings of $\$ 30,000$. 
courts reviewing committee recommendations; nevertheless, they suggest that courts should demand more extensive factual or legal support for a recommendation of dismissal if the suit appears meritorious, and that courts should be less critical if the suit seems frivolous.

Zapata could, and arguably should, encourage courts to undertake a thorough review of the recommendation of a special litigation committee. Unfortunately, the first level of review in Zapata incorporates terms and principles that can be used to undermine the impact of the case. Although the committee must prove its good faith and independence, the established criteria for good faith and independence are relatively easy to satisfy. Similarly, the requirement that the committee estabhish a reasonable basis for its recommendation is likely to be interpreted lemently in hight of the business judgment doctrine. For these reasons, the first level of review under Zapata is likely to be assimilated into the existing case law, and its impact will be minimal.

\section{The Second Level of Analysis Under Zapata: Considerations of Public Policy.}

1. Reaching the Second Level of Analysis. Under Zapata's second level of analysis, the reviewing court exercises its independent judgment to determine whether it should follow the recommendation of the special hitigation committee and dismiss the suit. In making its evaluation, the court may disagree that the corporation's interest would be best served by dismissal, or the court may decide that, despite the corporation's interest in dismissal, considerations of public policy require that the suit continue..$^{93}$ In theory, Zapata's activism is a welcome change from the passivity that predominates the Auerbach approach.

There are, however, two unfortunate aspects of Zapata's second level of analysis. First, a second level review is only available after the court determines, under the first level of analysis, that the suit is not frivolous. ${ }^{94}$ Thus, if the court finds that the committee had a reasonable basis for its conclusion that the suit lacks legal merit and should therefore be dismissed, the court cannot use its discretion to reject the committee's recommendation under Zapata's second level. Only in cases in which there was no reasonable basis for the committee's con-

No doubt the poor chance of success on the merits made even these terms attractive. $C$. Gaines v. Haughton, 645 F.2d 761 (9th Cir. 1981), cert. denied, 102 S. Ct. 1006 (1982) (dismissing causes of action similar to those in Shlensky). For a discussion of cost-benefit analysis of derivative suit litigation, see supra note 78.

93. 430 A.2d at 789 .

94. Id. 
clusion that the suit is frivolous may the court go on to its second level of review and decide whether the committee's recommendation to dismiss should be followed even though the suit is not frivolous. ${ }^{95}$

Many of the considerations that may prompt a committee to argue agamst the continuation of the suit involve matters outside the judiciary's experience. For example, the corporation can calculate the impact of the suit on employee expectations and morale and can answer other questions peculiar to the firm; however, the court's ability to review such issues is necessarily limited. On the other hand, courts are experienced in exercising their independent judgment in regard to the suit's legal merits. It would be more reasonable to allow the court to exercise its independent judgment on all matters within its competence than to restrict the second level of analysis to nonfrivolous suits in which the committee's decision rests largely on factors beyond the courts' normal experience.

2. Limitations on the Public Policy Inquiry. Equally troubling is Zapata's invitation to courts to give "special consideration to matters of law and public policy in addition to the corporation's best interest."96 This suggests that even if dismissal is in the corporation's best interest, that interest must give way to broader societal concerns protected by estabhished public policy. Lasker v. Burks ${ }^{97}$ was the first case to suggest that a committee's recommendtion may be ignored if it conflicts with public policy. The derivative suit plaintiff in Burks alleged that an investment company's adviser and some of its directors had

95. Two courts purporting to follow Zapata have stated in dicta that courts may exercise their independent judgment in reviewing a committee's recommendation; these courts did not acknowledge that Zapata limited this phase to non-frivolous suits. See Maldonado v. Flynn, 671 F.2d 729 (2d Cir. 1982); Watts v. Des Moines Register \& Tribune, 525 F. Supp. 1311 (S.D. Iowa 1981). After determining that the committees in Maldonado and Watts were mdependent and acted in good faith, the courts required each committee to develop further the factual rccord in support of its recommendation but did not review the committee's results. The cases therefore shed no light on the level of judicial review that courts will undertake following Zapata.

In a recent case, the Court of Appeals for the Second Circuit interpreted Zapata as inviting review of the committee's independence, good faith, and reasonable investigation, but not the bases for its decision. See Joy v. North [Current] FED. SEc. L. REP. (CCH) $\uparrow 98,860$ at 94,441 (2d Cir. 1982). The court, although purporting to follow Zapata, held that a court must always proceed to the second level of analysis and exereize its own independent judgment. Even though the court in Joy appears to violate the Zapata formulation of the review process, the result in Joy may nevertheless be consistent with Zapata: Joy clearly involved a nonfrivolous derivative suit, and the court found the factual bases that the committee presented to support its recommendation internally inconsistent. $I d$. at 94,444-45. The Joy court's holding that a court must always exercise independent judgment presents a welcoine change froin the overly deferential role envisioned in Auerbach, however, and the Joy formulation is preferable even if it is inconsistent with Zapata.

96. $430 \mathrm{~A} .2 \mathrm{~d}$ at 789 .

97. 567 F.2d 1208 (2d Cir. 1978), rev'd, 441 U.S. 471 (1979). 
recommended purchases that violated the Investment Company Act of 1940 and the Investment Advisers Act of 1940.98 A committee of five directors, who were neither affiliated with the investment adviser nor named in the suit, recommended dismissal of the action. The Court of Appeals for the Second Circuit held that to dismiss the suit on the basis of the independent directors' decision would be inconsistent with the policy of the Investment Company Act, ${ }^{99}$ but the Supreme Court reversed. ${ }^{100}$ The Court prescribed a two-stage analysis of the directors' decision to terminate derivative suits brought under federal statutes. The threshold inquiry is to determine whether the directors have the power under state law to terminate the derivative action. If they do, the court must then determine whether dismissal of the suit would be inconsistent with the policy embodied in the federal cause of action. ${ }^{101}$

The Court's second level of analysis in Burks had a very narrow focus. The Court exainined the structure and purpose of the Investment Company Act ${ }^{102}$ and its legislative history. Congress had rejected an amendment to the Act that would prevent directors froin terminating derivative suits; the Congress chose instead to address an array of conflict of interest problems through the Act's requirement that forty percent of the board of directors be dismterested and through specific requirements directed toward self-dealing transactions. ${ }^{103}$ To illustrate circumstances in which a committee's decision to terminate a derivative suit would seriously conflict with federal law, the Burks Court referred to section 36(b) of the Investment Company Act ${ }^{104}$ and section 16(b) of the Securities Exchange Act. ${ }^{105}$ In these statutes, Congress tailored the

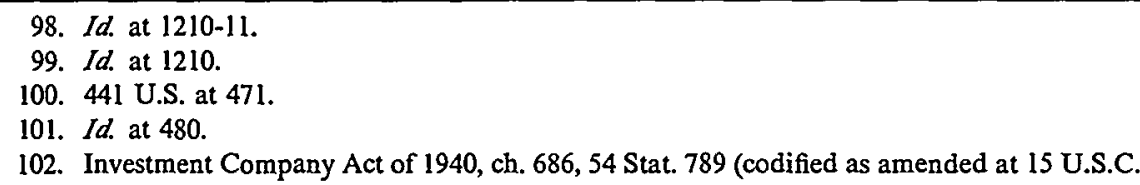
$\S 80$ a et. seq. (1976 \& Supp. IV 1980).

103. 441 U.S. at $482-85$. As the Burks Court also observed, id. at 484 , in 1970 Congress amended section 36 to add section 36(b). Subsection (2) of that section implores courts to give only such weight as they beheve appropriate to board decisions that approve coinpensation. See Pub. L. No. 91-547, 84 Stat. 1429 (codified as amended at 15 U.S.C. $\$ 80 \mathrm{a}-35$ (b) (1976)). PostBurks cases, however, have not viewed subsection (2) as excusing the demand requirement. See Grossman v. Johnson, 674 F.2d 115 (1st Cir. 1982); Markowitz v. Brody, [1981 Transfer Binder] FED. SEC. L. REP. (CCH) I 98,002 (S.D.N.Y. 1981). Pre-Burks cases reached the same result. See Untermeyer v. Fidelity Daily Income Trust, 79 F.R.D. 36, 44-46 (D. Mass.), vacated on other grounds, 580 F.2d 22 (1st Cir. 1978); Boyco v. Reserve Fund, Inc., 68 F.R.D. 692,696 (S.D.N.Y. 1975). The Court of Appeals for the Second Circuit recently held that Congress did not intend the action to recover excessive management fees under section $36(\mathrm{~b})$ to be a corporate action for which a demand on the directors is required. Fox v. Reich \& Tang, Inc., [Current] Fed. SEC. L. REP. (CCH) I 98,845 (2d Cir. 1982).

104. 15 U.S.C. $\& 80 \mathrm{a}-35$ (b) (1976).

105. Id. $\S 78 \mathrm{p}(\mathrm{b})$. This provision prohibits short-swing trading for a profit by insiders. 
procedural requirements for maintaining a derivative suit with great specificity: section 36(b) directly addresses the degree of deference to be accorded director or shareholder approval of management fee contracts, ${ }^{106}$ and section 16(b) specifies that a derivative action may be maintamed if a corporation refuses to sue. ${ }^{107}$ The Court reasoned that these statutes addressed directors' discretionary powers with such particularity that it would be inconsistent to infer that Congress intended to grant directors the power to dismiss the suit. ${ }^{108}$ The statutes both explicitly refer to the directors' decision not to sue; in contrast, the statute at issue in Burks contained no such reference.

To illustrate the policy considerations, or more specifically the legislative intent that would override a coinmittee recoininendation that a derivative suit be dismissed, the Burks Court pointed to two private causes of action expressly created by Congress. By contrast, the causes of action in Burks were merely implied. Only within statutes that expressly authorize a cause of action are the procedural requireinents for suit described with sufficient particularity to warrant the inference under Burks that Congress did not intend the directors to have power to dismiss the suit. Under the implied causes of action, where the great bulk of derivative suit litigation under the securities laws occurs, the statute's language does not deal with the procedural issues concomitant to private enforcement, and the legislative history is also silent on the question.

If a court were to reject a special litigation committee's recommendation in a suit under an implied cause of action, it would do so on the basis of a general perception that it is inore important to serve the public interest through private enforcement of the federal law than it is to serve the corporate interest by disimissal. This kind of reasoning occurs nowliere in Burks and is an impermissible extension of the Burks doctrine. ${ }^{109}$ Although the court in Zapata apparently approved such a re-

106. See 15 U.S.C. $\S 80 \mathrm{a}-35(\mathrm{~b})$.

107. See 15 U.S.C. $\$ 78 \mathrm{p}(\mathrm{b})$.

108. 441 U.S. at 484.

109. Even assuming that it is desirable to balance corporate and societal interests, the balancing process would not necessarily himit the prerogatives of the special litigation committee. As the court in Lewis $v$. Anderson noted:

Allowing disinterested directors to exercise their business judgment to dismiss what they see as groundless causes of action would in no way weaken the regulatory provisions of the federal securities laws. So long as those accused of manipulating the proxy vote are excluded from deciding whether or not to pursue the clain there is no conflict between the busimess judgment rule and $\S 14(\mathrm{a})$.

615 F.2d 778, 784 (9th Cir. 1979), cert. denied, 449 U.S. 869 (1980).

The courts in Lewis and all other post-Burks cases have consistently upheld the committee's recommendation even under Burks' second level of analysis after satisfying themselves that the committee's challenge to the federal action's merits and benefits was well justified. See, e.g., 
sult, it conflicts with accepted views of the purpose of derivative suits ${ }^{110}$ and would pose insurmountable problems. ${ }^{111}$

3. The Purpose of the Derivative Suit: Deterrence Versus Compensation. The second level of analysis in Burks and Zapata ${ }^{112}$ resurrects the time-worn question whether the purpose of derivative suits is to deter wrongdoing or solely to recompense the injured corporation. The statement in Zapata that courts should "give special consideration to matters of law and public policy in addition to the corporation's best interests" 113 sounds a hopeful note for those who emphasize the deterrent function of derivative suits. It is no coincidence that commentators who champion Zapata's second level of analysis are those who generally view the derivative suit as having a purpose quite apart from

Gaines v. Haughton, 645 F.2d 761 (9th Cir. 1981), cert. denied, 102 S. Ct. 1006 (1982); Abbey v. Control Data Corp., 603 F.2d 724 (8th Cir. 1979), cert. denied, 444 U.S. 1017 (1980); Maldonado v. Flynn, 485 F. Supp. 274, 281-82 (S.D.N.Y. 1980), aff'd in part and rev'd in part on other grounds, 671 F.2d 729 (2d Cir. 1982).

Decisions that evaluate a committee's recommendation under Burks are notable for the thoroughness with which the courts review the merits of the federal causes of action. There is a sharp contrast in these opinions between the courts' careful imspection of the alleged federal violation and their nearly coinplete abdication of any review function with respect to the state law claims, even though these claims were based on the same conduct that received careful scrutiny when it was the basis for a federal claim. See, e.g., Gaines v. Haughton, 645 F.2d 761 (9th Cir. 1981); Abbey v. Control Data Corp., 603 F.2d 724 (8th Cir. 1979); Rosengarten v. ITT, 466 F. Supp. 817 (S.D.N.Y. 1979); Gall v. Exxon Corp., 418 F. Supp. 508 (S.D.N.Y. 1976). Burks requires careful scrutiny of the federal claim before a court even begims to consider whether the committee's recommendation offends federal policy because Burks' second level of imquiry applies only to nonfrivolous federal clainis. Obviously, dismissal of a frivolous claim could not conflict with any legislative intent or established federal policy.

The inportance of the committee's independence to Burks public policy analysis cannot be emphasized too greatly. In Galef v. Alexander, 615 F.2d 51 (2d Cir. 1980), the Court of Appeals for the Second Circuit reasoned that the federal policy of full and fair disclosure im proxy solicitations would be frustrated if directors implicated in an alleged violation could cause the suit to be disınissed. Id. at 63 . In this way federal courts applymg Burks reinforce the state law requireinent of imdependence. It is not clear that the mdependence requirement, however satisfied, should be that inportant if the court has truly satisfied itself that the suit is of doubtful merit. Obviously, the committee's independence is reassuring in cases in which the suit is not patently without merit. This sense of reassurance nay be deceptive, however, because it is not possible for any definition of independence to screen out directors who are prone to the subtle influences of structural bias.

110. See infra notes 116-28 and accoinpanying text.

111. See infra notes $148-50$ and accompanying text.

112. There is an important difference between the second levels of analysis in Burks and in Zapata: consideratious of public policy are discretionary in Zapata and mandatory im Burks. Furthernore, only Zapata encourages the court to include in the second level of analysis its independent evaluation of the corporation's interest in dismissal. Unless state law mandates otherwise, the second level analysis under Burks will not disturb the directors' conclusion that disinissal would serve the corporate interest; the court only determines whether that unchallenged conclusion must give way to a federal policy that supports the contimuation of the suit.

113. 430 A.2d 779, 789 (Del. 1981). 
compensation. ${ }^{114}$ It is still too early to tell how this debate will be resolved in the context of the special hitigation committee cases. As discussed above, ${ }^{115}$ decisions in the wake of Burks offer no encouragennent to those who argue that courts should give less weight to the business purposes that support the committee's recommendation. Similarly, the courts have yet to invoke Zapata's second level of analysis to strike down a committee's recommendation. Because the courts have not been presented with a committee recommendation for the dismissal of a non-frivolous action, the full reach of either precedent remains to be tested. Nevertheless, there is good reason to believe that if a committee recommends that a non-frivolous suit be dismissed in the corporate interest, and a strong public policy favors its continuation, the corporate interest should prevail. The question whether the primary purpose of the derivative suit is deterrence or compensation has arisen in other areas, and in each case the goal of compensation has prevailed.

For example, suppose that the derivative suit defendant knowingly violates a state or federal criminal statute to the corporation's benefit. Commentators have sometimes envisioned that in such a case the derivative suit can operate in tandem with a public prosecution to further the public policies that underhe criminal statutes. ${ }^{116}$ Language in a few older cases equates violations of criminal statutes with breaches of common law fiduciary duties. ${ }^{117}$ If deterrence were the function of the derivative suit, these precedents would continue to govern today, ${ }^{118}$

114. See, e.g., Coffee \& Schwartz, supra note 49 at 287, 300; Schwartz, Response: Some Thoughts on The Director's Evolving Role, 30 Hastings L.J. 1405, 1409-10 (1979).

115. See supra note 109.

116. See Coffee \& Schwartz, supra note 49, at 287, 300; Schwartz, supra note 114, 1409-10. But see Blake, The Shareholders' Role in Antitrust Enforcement, 110 U. PA. L. REv. 143 (1961) (directors and officers should be shielded from personal hability for violations of crimmal statutes that benefit the corporation).

117. See Abrams v. Allen, 297 N.Y. 52, 55-56, 74 N.E.2d 305, 307 (N.Y. 1947); Roth v. Robertson, 64 Misc. 343, 346, 118 N.Y.S. 351, 353 (N.Y. Sup. Ct. 1909). Although Abrams and Roth were cited with approval in Miller v. AT\&T, 507 F.2d 759, $762-63$ (3d Cir. 1974), Miller substantially qualified their holdings by requiring proof of independent damages before the corporation can recover for a knowing criminal violation. Id. at 763 n.5. Roth's language itself behies the notion that recovery can occur without proof of imjury to the corporation. In dicta, the Roth court reasoned that the directors are hable for an unlawful act through which "they cause loss to the corporation," 64 Misc. at 345,118 N.Y.S. at 353 , and the court rcfers repeatedly to the nced to impose hability to deter wasting the corporation's assets, $i d$. at 346, 118 N.Y.S. at 353-54. Similarly, a crucial paragraph in the complaimt in Abrams alleged that the directors' decision to close the plant was not motivated by a desire to further the corporation's interests, but by "malice, bias and personal prejudices" toward the organizing efforts of its workers, 297 N.Y. at 55, 74 N.E. 2d at 306 , and the plaintiff alleged that the corporation suffcred a financial loss because of the plant closing, id

118. Coffee, supra note 10 , at $1166-72$, recounts the weaknesses of these precedents. 
and proof of a public injury would enable the corporation to recover regardless of the net effects of the litigation on the corporate fisc.

The prevailing rule is otherwise. The plaintiff must establish not only that the criminal act gave rise to an economic loss to the corporation, but that the resulting loss was greater than the competitive benefits garnered through the violation.119 This "net loss" approach to the corporation's right to recover for its fiduciary's illegal acts suggests that when continued prosecution of a meritorious derivative suit will not yield a net benefit to the corporation, the corporation should be able to terminate the suit. In each imstance, courts subordinate public policy to the crass accounting question of whether dismissal or continuance produces a net gain to the corporation. 120

To suggest that the Supreme Court's invocation of public policy considerations in Burks invites courts to favor the deterrent aspects of derivative suits over a determination that dismissal avoids a net loss to the corporation would be inconsistent with the Supreme Court's earlier position in Bangor Punta Operations, Inc. v. Bangor \& Aroostock Railroad.121 Through its wholly owned subsidiary, Bangor Punta Corporation acquired 98.3 percent of the stock of Bangor \& Aroostock Railroad (BAR) and later sold those shares to Amoskeag Coinpany at their fair value. Once in control of BAR, Amoskeag caused BAR to sue Bangor Punta and its subsidiary for funds allegedly misappropriated from BAR by the defendants during their years of control. The Court of Appeals for the First Circuit refused to dismiss the action by BAR, relying in part on the need to deter misinanagement, particularly among quasi-public corporations such as BAR.122

The Supreine Court rejected this reasoning, however, holding instead that considerations of deterrence do not justify a corporate recovery. ${ }^{123}$ The Court pierced the plaintiff's corporate veil and held that a

119. Siles v. Elfred, 149 N.Y.L.J., Feb. 20, 1963, at 14, col. 6 (N.Y. Sup. Ct.); Borden v. Cohen, 231 N.Y.S.2d 902 (1962); Clayton v. Farish, 191 Misc. 136, 73 N.Y.S.2d 727 (N.Y. Sup. Ct. 1947); see also, Miller v. AT\&T, 507 F.2d 759 (3d Cir. 1974); Forte, Liabilities of Corporate Officers for Violations of Fiduciary Duties Concerning the Antitrust Laws, 40 IND. L. REv. 313, 333-39 (1965); Note, Pleading and Proof of Damages in Stockholders Derivative Actions Based on Antitrust Convictions, 64 COLUM. L. REv. 174 (1964).

120. The weakness of this approach is that it allows estabhished public policy to be pushed aside by fairly indefinite accounting inputs. Solne suggest that this weakness could be remedied by taking a compromise position in the deterrence-coinpensation debate and shifting the burden of proof to those who seek to show that the suit will not result in a net gain to the corporation. See Coffee, supra note 10 , at 1220 . If this is what is required to salve those uneasy with a net loss mquiry, they will be pleased with Zapata, whicl accoinplishes this shift in the burden of proof. See supra notes 70-74 and accompanying text.

121. 417 U.S. 703 (1974).

122. 482 F.2d 865,868 (1st Cir. 1973).

123. 417 U.S. at 717 . 
purchaser of shares at their admittedly fair price cannot then sue the seller for mismanagement; if such suits were allowed, the new shareholders would recover for wrongs done to the previous owners. The Court viewed proof of loss as indispensable to a suit by the corporation.

Bangor Punta is the Supreme Court's acceptance of then Commissioner Pound's reasoning in a classic decision, Home Fire Insurance Co. v. Barber. ${ }^{124}$ Pound responded to the deterrence argument advanced by a corporation whose sole owner purchased the corporation's shares from the defendant at an admittedly fair price:

It is not the function of courts of equity to administer punishment. When one person has wronged another in a matter within its jurisdiction, equity will spare no effort to redress the person injured, and will not suffer the wrongdoer to escape restitution to such person through any device or technicality. But this is because of its desire to right wrongs, not because of a desire to punish all wrongdoers. If a wrongdoer deserves to be punished, it does not follow that others are to be enriched at his expense by a court of equity. A plaintiff must recover on the strength of his own case, not on the weakness of the defendant's case. It is his right, not the defendant's wrongdomg, that is the basis of recovery. ${ }^{125}$

It is clear that fear of unjustly enriching the owner of the plaintiff corporation underlies the holdings in Barber and Bangor Punta. ${ }^{126}$ Concern over unjust enrichment is not, as some have suggested, ${ }^{127}$ separable from the question of whether the derivative suit is to serve a compensatory or a deterrent function. If the defendant's wrong has caused no injury to those who would benefit from a corporate recovery,

124. 67 Neb. 644,93 N.W. 1024 (1903). For some interesting extensions and refinements of Barber, see Rock River Sav. \& Loan v. American States Ins. Co., 594 F.2d 633 (7th Cir. 1979) (suit against an accounting firm, not the managers from whom the plaintiffs sole stockholder acquired its shares), and Jannes v. Microwave Communications, Inc., 385 F. Supp. 759 (N.D. III. 1974) (derivative suit initiated by a minority stockholder against defendants who sold $90 \%$ interest after defrauding the controlled corporation).

The Court suggested in Bangor Punta that recovery may in appropriate cases be made on a pro-rata basis in a mmority-initiated suit. 417 U.S. at 711. In In re Pittsburgh \& Lake Erie R.R. Sec. \& Antitrust Litig., 387 F. Supp. 906 (E.D. Pa. 1974), however, the court rejected this suggestion out of concern for creditor protection.

125. $67 \mathrm{Neb}$. at $673,93 \mathrm{~N} . \mathrm{W}$. at 1035.

126. Other concerns also bar recovery in Bangor Punta and similar cases, see Bangor Punta, 417 U.S. 703, 716-17 (1974); In re REA Express, Inc., 412 F. Supp. 1239 (E.D. Pa. 1976), and explain the exceptions that have been made in the doctrine, see, e.g., Mauck v. Mading-Dugan Drug Co., 361 F. Supp. 1314 (N.D. Ill. 1973); Platt Corp. v. Platt, 21 A.D.2d 116, 249 N.Y.S.2d 75 (1964), affd per curiam, 15 N.Y.2d 705, 204 N.E.2d 495, 256 N.Y.S.2d 335 (N.Y. 1965). See generally, Note, Corporate Incapacity to Sue Where Stockholders Would be Barred from Suing Derivatively-The Vicarious Incapacity Rule: A Public Interest Exception, 54 B.U.L. REv. 355, 389 (1974). For a view that even private actions under the securities laws must be compensatory, see Fridrich v. Bradford, 542 F.2d 307 (6th Cir. 1976), cert. denied, 429 U.S. 1053 (1977).

127. See Corporate Governance, supra note 21 , at 239 (embracing the deterrent function of the derivative suit). 
the recovery cannot be justified on grounds of compensation because any such recovery would, by definition, be a windfall. Avoiding unjust enrichment and refusing to justify recovery on the grounds of deterrence are therefore corollary principles.

The special litigation committee cases give courts even stronger reasons to eschew derivative suits that liave solely a deterrent function. The corporation in Bangor Punta, driven by the desire to reap a $\$ 7$ million return on its $\$ 5$ million purchase of BAR, sought to prosecute a suit against a recognized, active wrongdoer. In the special litigation committee cases that trigger Burks' and Zapata's requirement that a court balance the net gain to the corporation against the public interest in deterrence, however, the corporation does not want to be a party to the action because the action will probably result in a net loss. ${ }^{128}$ If deterrence was an insufficient reason to allow the corporation to reap a benefit in Bangor Punta, it is difficult to imagine how deterrence can justify forcing a corporation to suffer a net loss in cases decided under Burks.

To be consistent with the historical, compensatory purpose of the derivative suit, the court should address only considerations important to the corporation from a financial standpoint under Zapata's second level of analysis. Other legal rules or considerations have not been sufficient in the past to permit continuance of the derivative suit. ${ }^{129}$ Therefore, the consideration of public policy called for under Burks and Zapata should not affect the prerogatives of the special litigation committee. Only im those rare situations foreseen in Burks in which Congress has carefully tailored the substantive and procedural elements of an express cause of action to preclude termination of the suit

128. In order to reach the second level of analysis under Zapata, the court must first decide that the suit is not frivolous. If the court believed the suit frivolous, it would have dismissed it before reaching the second level of analysis. See supra note 94 and accompanying text. Therefore, if a court rejects a committee's conclusions under Zapata's second level of analysis, it will risk causing the corporation a net economic loss. A committee may offer unimpeachable findings that the corporation can expect to recover $\$ 200,000$ from the suit, but that its costs, plus the value of other losses sustamed in proseeuting the action, will be $\$ 300,000$. The court, in the interest of public policy, could require that the corporation snffer a net loss of $\$ 100,000$ by continuing the suit. Ignoring the committee's justification for dismissal not only conscripts the corporation to vindicate the public interest, it also visits on the corporation costs and losses in excess of the expected benefits of the suit.

129. The possibility that the public interest will be vindicated by criminal or administrative enforcemcnt of the fcderal or state law inay console those wlio are uneasy that unlawful conduct will go undeterred or unprosecuted. See, e.g., In re REA Express, Inc., 412 F. Supp. 1239 (E.D. $\mathrm{Pa}$. 1976). Furtherunore, creditors of the injured corporation may independently obtain relief for damage to their debtor. See Capital Wine \& Spirit Corp. v. Pokrass, 277 A.D. 184, 98 N.Y.S.2d 291, 292 (1950), affd mem., 302 N.Y. 734, 98 N.E.2d 704 (1951). 
by the corporation should public policy considerations thwart the recommendation of the special litigation committee.

\section{The Proposal Before the American LaW Institute}

In a thoughtful and sweeping review of "what ails the derivative suit," Professors Coffee and Schwartz propose provocative legislative reforms for the conduct of derivative suits. These reforms restrict the availability of special hitigation committees and expand the watchdog role of the courts that review committee recommendations. ${ }^{130}$ Coffee and Schwartz envision the committee as an investigative arm for a larger deliberative body of independent directors made up of no fewer than a majority of the corporation's directors. ${ }^{131}$ The court would be

130. See Coffee \& Schwartz, supra note 49 , at $326,330-36$.

131. Id. at 320-26. Coffee and Schwartz envision some change in the board's mcmbership between the initiation of the suit and the formation of a special litigation committee because their proposal allows a majority of the independent directors to bar the derivative suit if such a majority exists when the recommendation is inade to the court. Id. at 333 (section 49(e)(1)); see also Dent, supra note 10, at 122-24.

Coffee and Schwartz expand the size of the independent recommending body beyond its prevalent three person inembership on the theory that independence requires a "critical mass" of unaffiliated directors to offset the effects of structural bias. Coffee \& Scliwartz, supra note 49, at 323; see also Dent, supra note 10, at 122-23. Although it may be more difficult for the defendants to locate seven or eight coinpliant and right-minded noininees than to locate two or three, Coffee and Schwartz's proposal does not remove the defendants from the selection process. The defendants' involvement at this critical juncture contributes greatly to the special litigation committee's structural bias; even under Coffee and Schwartz's formulation, the majority of the committee may be psycloologically committed in advance to the defendants' position. See id. at 124 .

The defendants' influence in the selection of the independent body is more removcd if candidates to the board are closen by a nominating committee. See generally Conard, Mace, Blough \& Gibson, Functions of Directors Under the Existing System, 27 Bus. Law. 32, 35-36, 41-46 (Spec. Issue 1972) (true director independence can exist only if a corporation has an independent nominating cominittee); Eisenberg, Legal Models of Management Structure in the Modern Corporation: Officers, Directors, and Accountants, 63 CALIF. L. REv. 375, 408 (1975). Because a nominating committee separates the defendants from the body of directors that determines the corporation's mterest in the derivative suit, one commentator lias argued that if a noininating committee is used to select the directors who will review the suit's prospective costs and benefits, the court should defer if the directors decide that the hitigation is not in the corporation's best imterest. See Small, The Evolving Role of the Director in Corporate Governance, 30 Hastings L.J. 1353, 1388 n.99 (1979). Similarly, there is less concern over the propriety and accuracy of a recommendation to dismiss when the Securities Exchange Commission nommates directors for the special litigation committee. See Abramowitz v. Posner, 513 F. Supp. 120 (S.D.N.Y. 1981), affd, 672 F.2d 1025 (2d Cir. 1982).

Use of a nominating committee, lowever, does not solve the problem of structural bias. Even though the defendants cannot gerrymander the cominittee's composition and the cominitlee members need not fear retaliation by the defendants slould their recommendation favor the plaintiff, the cultural ties cominon to all directors may adversely disturb the committee's decision. Furthermore, derivative suits that employ special litigation committees generally involve public corporations, and available statistics reveal that only a distinct minority (34\%) of these firms have nominating committees. See SeC. Reg. \& L. ReP. (BNA) No. 634, at A-7 (Dec. 23, 1981). More importantly, although $72 \%$ of the board members of publicly traded firms are nonmanagement 
powerless to dismiss a derivative action in response to the committee's recommendation unless a majority of the larger body of independent directors also favored dismissal. 132

As the reporter for the ALI's Corporate Governance Project, Professor Coffee relaxes this requirement. ${ }^{133}$ Under the proposal before the ALI, the court inay consider a recommendation offered by a minority of the board even though the plaintiff imphicates a majority of the board in the alleged wrongdoing. ${ }^{34}$ The proposal borrows heavily from Zapata by requiring the court to make its own independent deter-

outsiders, see id, derivative suits generally implicate a majority of the directors, both affiliated and unaffiliated. Thus, even if a corporation has a nominating committee, it may fail to buffer effectively the special litigation committee from the defendants' influence because the defendants are likely to be members of the nominating committee. Selection of the nominating cominittee's nembership is open to every criticism aimed at the selection of special litigation committee mennbership; therefore, the mere existence of a nominating committee should not suffice to persuade a court of the legitimacy of the special litigation committee's recominendation. Rather, courts should weigh its presence as one of a lost of factors in the review process.

132. The first premise of Coffee and Schwartz's proposal is that the normative standards imposed on derivative suit litigation should offer incentives for public corporations to have a majority of their directors be independent of management. Therefore, courts are encouraged to defer to independent directors' decisions. Coffee \& Schwartz, supra note 49, at 321; see also Coffee, supra note 10, at 1229-41. Another cominentator, however, who also believes that courts should encourage independent boards by taking a noninterventionist approach, makes an exception to this rule when a special litigation committee decides not to pursue a derivative suit against a fellow director. Haft, Business Decisions by the New Board: Behavioral Science and Corporate Law, 80 MrCH. L. Rev. 1, 14 (1981).

If board independence is their goal, Professors Coffee and Schwartz should take heart from statistics that reveal that only a small percentage of publicly traded corporations do not have outside boards. See CoRPorate GoverNANCE, supra note 21, \$ 3.03 cominent a at 72-73; see also SEC. Reg. \& L. Rep. (BNA) No. 634, at A-6 (Dec. 23, 1981). There is nothing in Coffee and Schwartz's proposal, however, to stimulate corporations with management dominated boards to move toward outside boards. First, their proposal does not require the corporation to have had an independent board when the wrongdoing occurred or when the derivative suit was initiated. At any time through the suit's long hife a corporation may invoke the deference that Coffee and Schwartz afford to a special litigation committee by securing resignations and electing independent directors. Therefore, the proposal's value as an incentive for the creation of independent boards is reduced by the corporation's ability to wait and see whether it needs an indepondent board, with no concouritant loss in access to the special litigation committee. Second, there is no rcason for coinpanies not having outside boards to expect that they will be "trouble plagued" and more frequently the target of derivative suits, as Coffee and Schwartz suggest. See Coffee \& Schwartz, supra note 49, at 321. Corporations with manageinent dominated boards are not likely to perceive this lack of independence as a risk; for example, there is no evidence that companies that have moved to outside boards have done so to achieve a tactical weapon in the event a derivative suit arises.

133. Corporate Governance, supra note $21, \S 7.03$.

134. Id. $\$ 7.03(\mathrm{~b})(\mathrm{i})$. The proposal expressly contemplates that the recommendation will come from a committee, rather than froin the full board. $I d$. $\$ 7.03(\mathrm{c})$. Therefore, the board must follow the procedures recominended as "good corporate practice" for establishing an investigation committee where the majority of the board is imdependent. Id. \& 7.03(b). The cominents to section 7.03 do not fully address or explain this requirement but appear to follow the reasoning of Professors Coffee and Schwartz that a committee is a better fact gatherer (although their own 
mination that the business justification advanced in support of the committee's recominendation "(A) is not outweighed by the probable recovery or other rehef that the court determines is likely to result from the hitigation, (B) does not frustrate any authoritatively established public policy, and (C) is advanced im good faith . . .."135 Even if the independent directors coinprise a majority of the board, they cannot cause the dismissal of a derivative suit that alleges a self-dealing transaction with an individual "having control . . . over the corporation."136 Finally, the mdependent directors must base their recommendation on a substantial business justification other than the suit's worth on the merits. ${ }^{137}$

Two broad objectives underlie this proposal. First, it seeks to increase the courts' involveinent in the review of the directors' recom-

proposal limits the committee to performing an investigative function for a larger deliberative body of the board, see Coffee \& Schwartz, supra note 49 , at 323 ).

135. CoRPorate GovernanCE, supra note $21, \$ 7.03$ (c)(ii). To counter the argument that dismissal is necessary to avoid burdening the corporation with hitigation expenses greatcr than the expected recovery, the proposal before the ALI imcludes in the minimum damages recoverable the "cost and expenses foreseeably paid or mcurred to redress" a breach of loyalty. $1 d . \S 706$ (c). In settlement and nonloyalty cases, however, the assignment of such costs and expenses to the defendants is within the court's discretion. Id. There is reason to believe that these provisions will fail to be a complete solution. Most derivative suits are settled, Jones, An Empirical Examination Of The Resolution Of Shareholder Derivative And Class Action Lawsuits, 60 B. U.L. REv. 542, 54447 (1980), and the effect of the proposal on settlements is uncertaim. The assignment of costs is merely a factor to be considered in the court's review of the settlement, and the court may be persuaded not to impose such costs on the defendant by the questionable merits of the case, by the defendant's good intentions, or by his apparent rehabilitation.

It is also unclear how to apply the proposal when the corporation's success on the merits is uncertain. For example, if there is at best only a $40 \%$ chance of recovery, it is not clcar whether the committee, in weighing the costs and benefits of contimuing the suit, should include in its calculations the full cost of the hitigation (which the corporation must bear if it loses the suit), or whether it should disregard the hitigation costs (which, under the proposal before the ALI, the defendant will bear if the corporation wins). To reflect the uncertainty of recovery, the committee might include in its calculations some percentage of the expected costs.

A more basic problem with the proposal to the ALI is that in nonloyalty cases the assignment of costs may well never occur because the costs would cause recovery to excecd the ceiling imposed for fault in cases that do not involve a breach of loyalty. CORPORATE GOVERnANCE, supra note $21, \S 706(\mathrm{e})$. Even in loyalty cases, there are practical hinits to what can be recovered from a defendant who has limited personal assets; the assignment of costs to such a defendant may be an empty act. Finally, contrary to the unsupported statement in the cominentary, see id. at 390 , it is more likely that the corporation will protest the suit's continuation on economic grounds when the alleged wrongdoing is other than a breach of loyalty by insiders. Allegations that question business conduct are an attack on the corporation itself, not just on individual officers or directors, $c$. Otis \& Co. v. Pennsylvania R.R., 61 F. Supp. 905 (E.D. Pa. 1945), aff'd, 155 F.2d 522 (3rd Cir. 1946), and in such cases, the corporation is hikely to take a more active role in the litigation, which will raise the litigation costs.

136. CORPORATE GOVERNANCE, supra note $21, \S 7.03$ (c)(iii).

137. Id. $\$ 7.03(\mathrm{~b})($ iii). The proposal invites the court to evaluate the merits of the suit under section 7.03 (c)(ii), see supra text accompanying note 135 , when it determines whether probability of recovery outweighs the business justification in support of dismissal. 
mendation that a suit be dismissed. ${ }^{138}$ Second, by requiring judicial review of the directors' decision in all cases, the proposal seeks to avoid the death sentence for the derivative suit that almost automatically occurs when the demand on the board has not been excused. ${ }^{139}$ These two objectives are reasonable responses to the threat of structural bias. The weakness in the proposal lies not in its objectives, but in the standards it imposes on the courts' review.

\section{A. The Committee's Opinion of the Suit's Merits.}

Under the proposal before the ALI, the committee's recommendation that the suit be dismissed must be grounded on a substantial business justification other than the committee's opmion of the suit's merits. ${ }^{140}$ This requirement adopts Vice Chancellor Harnett's opinion in the lower court decision in Zapata that in "our system of law, courts and not litigants should decide the merits of litigation."141 The Vice Chancellor, however, was concerned about the directors' lack of legal acumen, not their structural bias. Committee members are not generally selected because they bring to their job the lawyer's talent for analysis of the facts and legal principles. Their contribution to the committee's mission is their purported independence, fairmindedness, and responsibility to advance the corporation's interests imposed by state law. It is the imvaluable role of counsel to the special hitigation committee to provide the legal talent necessary to assuage the Vice Chancellor's concern for the committee's coinpetence. ${ }^{142}$

The committee's task is not to make a final determination of a suit's legal merits. The committee's task is to offer an opinion of the risk-and-return possibilities of a suit and of its commercial impact. This assessment enables the court to consider the costs and benefits of

138. Id. \& 7.03(c)(ii).

139. The proposal to the ALI retains the demand requirement, CORPORATE GovernanCE, supra note $21, \S 7.02$ (b), but envisions that the demand is required "precisely in order to give the board an opportunity to take over the litigation or pursue internal reforms or sanctions," id. at 315. If a demand is inade and rejected, the directors' decision not to proceed is subject to judicial review under the same standards that are used to review a coinmittee's recommendation that a suit be dismissed. $I d . \S 7.03(\mathrm{a})(\mathrm{ii})$.

140. Id. $\S 7.03(\mathrm{~b})(\mathrm{iii})$.

141. Maldonado v. Flynn, 413 A.2d 1251, 1263 (Del. Ch. 1980) (quoted with approval in Zapata Corp. v. Maldonado, 430 A.2d 779, 789 n.18 (Del. 1981)).

142. Professor DeMott questions whether reliance on counsel is inconsistent with application of the business judgment rule. See DeMott, supra note 57, at 863-65. Case law and statutes, however, permit directors to rely on professionals and experts. See, e.g., CAL. CORP. CODE $\S 309$ (West 1977); MODEL BusINESS CORP. ACr $\S 35$ (1977). The leading case holding that the business judgment rule protects the directors' decision not to sue a third party is United States Copper Sec. Co. v. Amalgainated Copper Co., 244 U.S. 261 (1917). This case does not question the directors' coinpetence to render a decision on such a legal matter. 
the suit from the corporation's point of view. Whether the court will be persuaded by the committee's recommendation depends on the accuracy and adequacy of the committee's evaluation. Judicial review of the committee's recommendation should be as effective to detect structural bias when the justifications are based on the committee's opinion of the suit's merits as it is when the committee offers other justifications. In either case, the court must determine whether the recommendation is discordant with its estimation of the suit's worth. This type of judicial review is identical to the review that a court undertakes before it approves a proposed settlement, ${ }^{143}$ and the proponents of settlement are not prohibited from questioning the suit's merits. The Vice Chancellor's concern about the directors' legal skills would be warranted, therefore, only if the reviewing court were to accept uncritically the committee's appraisal of the suit's merits. As long as the court undertakes a searching review of the committee's evaluation, the court remams the final arbiter.

The requirement that the committee be prohibited from basing its recommendation on its opinion of the suit's merits has a more pragmatic weakness as well. The committee's evaluation of the suit's merits is not separable from the busimess justifications that the proposal permits the committee to consider. There is an important dynainic between the legal merits of the derivative suit and the other grounds that are appropriate bases for a committee recommendation, and even the commentary to the proposal recognizes that the committee carmot completely separate the business justifications for its recommendation froin its opinion of the suit's merits. ${ }^{144}$ Indeed, it would not be reasonable for a committee to opme that it had a substantial business justification for recommending dismissal unless it first made some evaluation of the suit's merits. ${ }^{145}$ The proposal simply requires the committee and the court to engage in the charade of using their inquiry into other justifications for the committee's recommendation as a surrogate for the committee's evaluation of the suit's merits and for the court's review of that evaluation.

143. See supra note 78.

144. See, e.g., Corporate Governance, supra note $21, \S 7.03$, comment c.

145. The proposal before the ALI does not require a court to reject a committee's report if it includes an assessment of the suit's merits. What the proposal appears to do is to remind the court that it is the court's function to review the suit's inerits. The proposal appears to suggest that there are two standards of review: one standard for evaluating the committee's business justifications, and another more demanding standard for evaluating the committee's opinion of the merits of the suit. Yet, in each case, the commentary describes the court's review as "de novo." Id. § 7.03, comment c. The proposal would be better if it called for a de novo review of all the grounds in the committee's report, and if those grounds were to include the committee's opinion of the suit's Inerits. This would encourage the committee to present its full thinking in one integrated package. 


\section{B. Affronts to Public Policy.}

Following Zapata, the proposal before the ALI also empowers the reviewing court to ignore the corporation's substantial business justifications for recommending dismissal if dismissal would frustrate "authoritatively established public policy." 146 This aspect of the proposal is subject to the criticisms directed at Zapata's second level of analysis. ${ }^{147}$ The illustration in the reporter's commentary demonstrates the unwieldiness of this type of inquiry. ${ }^{148}$ In the illustration, a corporation's general counsel was able to embezzle substantial suins as a result of defective internal controls that violated the Foreign Corrupt Practices Act. The reporter concludes that even if substantial business concerns justify dismissing the suit, ${ }^{149}$ dismissal would nonetheless thwart an "authoritatively established public policy" by allowing the corporation to perpetuate its inadequate system of accounting controls. This conclusion overemphasizes the importance of dismissal; clearly, disinissal does not preclude the corporation from taking preventive or corrective steps to discourage the alleged wrongful conduct. Indeed, in many special hitigation committee cases, corporations have voluntarily taken remedial action in the wake of a committee recommendation that the suit be dismissed. ${ }^{150}$

\section{Self-Dealing by a Control Person.}

The broadest limitation in the proposal before the ALI is its prohibition of dismissal at the request of the directors if the suit involves self-dealing between the corporation and a control person. ${ }^{151}$ This prohibition has a certain logical appeal: if a controlling stockholder is imphicated in the alleged wrongdoing, it may warrant a presumption that a inajority of the board of directors is not independent. Nevertheless, there is room for soine judicial flexibility in passing on a committee's independence in such cases. For exainple, the board may be free of the defendant's controlling interest because during the period between the

146. Id. $\S 7.03$ (c)(ii)(B).

147. See supra text accompanying notes 94-127.

148. See CoRPorate GovernaNCE, supra note $21, \S 7.03$, illustration No. 1.

149. Id. The reporter mentions the general counsel's years of good service and the effect of the suit on employee morale as reasons for recommending dismissal although he correctly notes that these justifications would virtually never be appropriate in an enbezzlement case.

150. See Payson, Dismissal of Derivative Actions: The Debate, 6 DEL. J. OF CORP. L. 522, 527 (1981).

151. Corporate Governance, supra note $21, \S 7.03$ (c)(iii). Courts may disiniss suits that inplicate a controlling stockholder in conduct that does not involve self-dealing by him or by others if the committee's recommendation satisfies the other requirements of section 7.03 , see supra text accompanying notes 135-37. 
initiation of the derivative suit and the formation of the committee the defendant sold control to another. Or the committee may be appointed under the supervision and advice of an outside regulatory body. ${ }^{152}$ Therefore, in at least these two instances, the committee may not be affected by the defendant's influence, and courts should be free to consider the particular circumstances of the committee's composition and selection, and the degree of the defendant's dommance, to ascertain whether the committee is actually independent. The proposal as currently drafted prevents such a flexible response. ${ }^{153}$

152. Abramowitz v. Posner, 513 F. Supp. 120 (S.D.N.Y. 1981), affd, 672 F.2d 1025 (2d Cir. 1982), presents this type of fact situation. See supra text accompanying notes 80-85.

153. The proposal contains a rather narrowly drafted technical section that permits the corporation to petition the court to appoint a special panel to study the derivative suit and make a recommendation to the court. CORPORATE GovernanCE, supra note 21, \& 7.03(f). Although this provision appears to provide special procedures for cases in which a controlling stockholder is accused of self-deaking through the corporation, its scope is in fact inuch narrower. The court may appoimt a panel only when the corporation is imcapable of appointing a coinunittee under the standards of independence embodied in section 7.03(e). Section 7.03(e) defines the term imdependent director as follows:

Independent Director: As used in this Section and $\$ 7.05$, the term "independent director" shall mean a director who (i) is able under the circumstances to exercise impartial, disinterested, and critical judgment with respect to the defendants in the action, (ii) if the action is agaimst any present or former senior executive [\$ 1.23] or person possessing control [\$1.04] over the corporation, has no significant relationship [\$1.24] with any semior executive of the corporation or any controlling person, (iii) was not elected to the board subsequent to the earler of the commencement of the action or the inaking demand by plaintiff therem, unless such election was by a vote of the shareholders at an annual meetimg on nommation by a committee of two or inore independent directors or, if to fill a vacancy on the board, by the vote of a committee of two or more independent directors, in either case without the active participation of any defendants in the action, and (iv) is not a defendant in the action; provided, however, that the naming of a director as a defendant in the action shall not alone disqualify the director from serving as a member of the committee, or otherwise participating in the appoimtment or election of a new director to serve on such a committee, if the court finds that the inclusion of the director as a defendant was without merit. In determinimg both whether a dircctor is able under the circuinstances to exercise impartial, dismterested, and critical judgment and the credence to be accorded any justifications offered for dismissal by a comnnittce of such directors, the court (A) may consider whether the director was elected or appointed to the board by an independent nominating comınittee that complies with the standards specified in $\$ 3.06$, and (B) shall give substantial weight to (i) whether under the circumstances deinand on the board would have been required or excused as futile under traditional principles because of the substantial involvement of directors in the action as defendants, and (ii) whether any investigation or other action commenced by the board, or a committee thereof, prior to the earlier of the making of demand or the filing of the action demonstrates the exercise of critical scrutiny by the board or cominittee of the defendant's conduct.

Id. $§ 7.03(\mathrm{e})$.

If the defendant is no longer the corporation's controlling stockholder, the directors could satisfy the independence criteria of section 703(e). Therefore the court could not appoint a special pancl; yet, under section 703(f), the corporation could not avail itself of the special litigation coinimittee. This may be the result of a drafting oversight; presumably, the drafters intended to require that courts, not the corporation, appoint the panel in cases involving self-dealing by a controlling stockholder. However, it is not clear why this limited area of corporate fiduciary litigation ought to be singled out for special treatment. 
1. Misplaced Reliance on Clark v. Lomas \& Nettleton Financial Corp. With respect to suits against a controlling stockholder in which there is no allegation of self-dealing, the proposal before the ALI offers a more demanding standard for judging committee independence than that currently imvoked by the courts. ${ }^{154}$ The reporter's commentary does not clearly explaim why this higher standard is not sufficient when there are allegations of self-dealing by a control person. The first of two arguments ${ }^{155}$ that the reporter advances in support of the special treatment of self-dealing cases relies on Clark v. Lomas \& Nettleton Financial Corp. ${ }^{156}$ but this case appears to support the wisdom of the proposal's definition of mdependence far better than it supports an absolute ban on the use of a special litigation committee when there are allegations of self-dealing by a control person.

In Clark, NCS Computer Corporation (NCS) merged with Booth, Inc. The stockholders of the new corporation initiated a derivative suit agaimst Lomas \& Nettleton Financial Corp. (LNFC), the former controlling stockholder of NCS. For three years, the directors of Booth, Inc., took no part in the litigation despite two demands made on thein under rule 23.1. The complamt was then amended to add as defendants certaim officers of Booth, Inc. and Jack Booth, the controlling stockholder; the new defendants allegedly aided and abetted LNFC in dismantling NCS's successful computer operations. By adding Jack Booth as a defendant the plaimtiff awakened a sleeping giant. Booth, Inc. joined the defendants im a motion to dismiss the actions and later entered into a settlement with all of the defendants. ${ }^{157}$ The Court of Appeals for the Fifth Circuit, in what it referred to as a "parity of reasoning"158 to cases excusmg the demand requirement, vacated the district court's approval of the settlement. ${ }^{159}$ The appellate court reasoned

Section 703(f) is also inconsistent with other parts of the proposal because a recommendation of dismissal froin a court-appointed panel unay not be ignored on the grounds that dismissal would contravene established pubhic pohcy. Id. $\$ 7.03(\mathrm{f})$. The commentary does not explain why the need for deterrence is persuasive when a special litigation committee offers a recommendation, see supra notes 146-50 and accompanying text, but not when a panel chosen by the court issues the recommendation.

154. Corporate Goverfance, supra note $21, \$ 7.03(\mathrm{e})$.

155. Id. \$ 7.03, comment $\mathrm{d}$, at 327-28.

156. 625 F.2d 49 (5th Cir. 1980), cert. denied, 450 U.S. 1029 (1981).

157. Id. at 50-51. The Fifth Circuit opinion suggests that the plaintiffs were foreclosed from these settlement negotiations." Id. at 51. The trial transcript, however, slows that the district court judge provided the impetus for the settleinent negotiations, and that the plaintiff participated in the negotiations. See Clark v. Loinas \& Nettleton Fin. Corp., 79 F.R.D. 641,645 (N.D. Tex. 1978). The plaintiff was not a party to the final proposal only because the defendants were unwilling to settle the plaintiff's individual claim along with the derivative suit. See id.

158. 625 F.2d at 54.

159. Id. 
that the directors of Booth, Inc. were incoinpetent to approve a settlement because they were under the control of defendants Jack Booth and LNFC. The uncontroverted evidence showed that Jack Booth and LNFC elected all the directors to the board of Booth, Inc. and that a majority of the directors were corporate officers or employees. ${ }^{160}$

The significance of Clark should not be misinterpreted. Although Jack Booth was a controlling stockholder of Booth, Inc., when the settlement was proposed, he was not a controlling stockholder of NCS when the alleged harms occurred; Mr. Booth was implicatcd as the alleged aider and abettor of someone else who was in control. Because the complaimt focused on the transfer of NCS's computer business to LNFC and not to Booth, Inc., Jack Booth was not engaged in selfdealing. It is inappropriate to cite Clark as evidence of a court's unwillingness to defer to directors' recommendations in suits that allege self-dealing by a controlling stockholder; Clark questions director impartiality in any suit against a current control person.

The procedures in the proposal before the ALI for determining director imdependence, ${ }^{161}$ and particularly for the appointment of new directors to serve on a special litigation committee, ${ }^{162}$ offer a workable response to the problem presented in Clark. The directors in Clark were appointed after the derivative suit was initiated. Unless they were elected by a vote of the stockholders at an annual meeting after nomination by a committee of independent directors, or chosen by independent directors to fill a board vacancy, these directors would be ineligible for special litigation committee membership under the proposal. In either case, defendants Jack Booth and LNFC would have had no active role in their nommation or election. ${ }^{163}$ The criteria for director independence under the proposal suffice to solve the problem posed by the facts in Clark, and Clark offers no support for the theory that self-dealing transactions are a special subspecies of controlling stockholder misconduct that is beyond the reach of a committee of independent directors. Nor does Clark question a cominittee's competence to settle a derivative suit. ${ }^{164}$ Therefore, the reporter's reliance on Clark to justify special treatment for cases involving self-dealing by controlling stockholders is misplaced.

160. Id. at 52-54.

161. Corporate Governance, supra note $21, \S 7.03(\mathrm{e})$.

162. Id. $\S 7.03(\mathrm{~b})$.

163. $I d . \S 7.03(\mathrm{e})$.

164. The Clark court recognized that an independent committee may have been able to "achieve what the directors unsuccessfully attempted." 625 F.2d at 54 n.6. 
2. Misinterpretation of State Conflict of Interest Statutes. The reporter's second argument in support of the proposal's special treatinent of self-dealing by control persons is that it would be inconsistent with state conflict of interest statutes to dismiss an action involving self-dealing on the basis of a committee recommendation. ${ }^{165}$ Solne commentators have argued that under state conflict of interest statutes, only a court may approve a self-dealing transaction after the transaction has taken place. ${ }^{166}$ Only a court is sufficiently insulated to judge the fairness of the transaction. The rationale behind this limitation is that because the directors will be less willing to rescind a self-dealing transaction once it has been consummated, ${ }^{167}$ they are not permitted to approve self-dealing transactions retrospectively. To allow a special litigation committee to protect a self-dealing transaction froin attack in a derivative suit wonld be equivalent to permitting them to approve the transaction in retrospect, and this would circumvent the supposed purpose of the conflict of interest statutes. ${ }^{168}$

Most state conflict of interest statutes clearly allow disinterested directors to approve retrospectively transactions between an officer or director and his corporation. ${ }^{169}$ A distimct minority of the statutes,

165. CORPORATE GOVERNANCE, supra note $21, \S 7.03$, comment d, at 327-28.

166. Professor Buxbaum was the first to make this argument. See Buxbaum, Conflict-of-Interests Statutes and the Need for a Demand on Direetors in Derivative Actions, 68 CALIF. L. REv. 1122 (1980).

167. Id. at 1127.

168. Accepting this interpretation of the state conflict of interest statutes would not compel the line-drawing embodied in the proposal before the ALI. The proposal addresses self-dealing by controlling stockholders, see supra note 151 and accompanying text, but state conflict of interest statutes are concerned with dealings between the corporation and its directors or officers, or between the corporation and another corporation im which a director or officer has an interest. See, e.g., CAL. Corp. Code §310(a) (West 1977); Del. Code ANN. tit. VIII, § 144(a) (1975); N.Y. Bus. CORP. LAW § 713(a) (McKinney Supp. 1971); MODEL Business CoRP. ACT \& 41 (1977). The statutes do not proscribe transactions between a corporation and its controlling stockholder if the controlling stockholder is not also a director of the corporation. Acceptance of Professor Buxbaum's thesis, therefore, should require special provisions in the proposal before the ALI for cases that involve self-dealing by directors or officers, not self-dealing by controlling stockholders (except where the control person is also a director or officer).

169. See Ala. Code § 10-2A-63 (1) (1980); ARIz. Rev. STAT. ANN. § 10-04(a)(1)(1977); Cal. CoRP. Code §310(a)(2)(West. 1977); Colo. Rev. Stat. \& 7-5-114.5 (Supp. 1981); Fla. Stat. ANN. $\$ 607.124$ (1)(a) (West 1977); IDAHO CODE § 30-1-41(a) (Supp. 1982); KY. Rev. Stat. ANN. § 271A.205(1)(a) (Baldwin 1973); ME. Rev. STAT. ANN. tit. 13-A, § (1)(a) (1981); MD. CoRPs \& Ass'Ns CODE ANn. § 2-419(b)(1)(i) (Michie Supp. 1981); Mich. Bus. CoRP. ACT \& 545(b); MONT. Code ANN. § 35-1-413 (1)(a) (1981); Neb. Rev. Śtat. § 21-2040.01(1) (1977); Nev. Rev. Stat. \$ 78.140(1)(a) (1981); N.H. Rev. Stat. ANN. § 293-A:41(I)(a) (Supp. 1981); N.J. STAT. ANN. \$ 14A:6-8(1)(b) (West Supp. 1982-1983); N.Y. Bus. CoRp. LAw 713(a)(1) (McKinney 1963 \& Supp. 1981-1982); N.C. GeN. STAT. \$ 55-30(b)(1)(1975); OR. Rev. STAT. § 57.265(1)(a) (1981); S.C. CODE ANN. \& 33-13-160(a)(1) (Law. Co-Op. 1976); TENN. CODE ANN. § 48-816(1)(a) (1979); Vt. Stat. ANN. tit. 11, § 1888 (1973); VA. Stock CoRp. Act 13.1-39.1(i); W. VA. CoRP. ACt 31- 
however, provide only that the board of directors may "authorize the contract or transaction." 170 This language suggests that even independent directors cannot retrospectively approve a self-dealing transaction and that retrospective approval could therefore only occur after a judicially superintended inquiry into the transaction's fairness. The legislative history of the statutes, however, rejects this interpretation.

Conflict of interest statutes were enacted to reverse restrictive and ambiguous case authority that night be used to void transactions solely on the basis of a director's or officer's interest in the transaction. ${ }^{171}$ Through the statutes, legislatures sought to extend presumptive validity to these self-dealing contracts and to articulate procedures by which the parties to the transaction could obtain director or stockholder approval. These objectives are clearly expressed in the statutes' introductory clauses, which state that if the parties comply with the statutory procedures, the "transaction or contract will not be void or voidable solely because of the officer's or director's interest." 172

The conflict of interest statutes do not address the abuses that arise in conncction with unfair self-dealing contracts entailing a director's or officer's breach of a fiduciary obligation. Even though a transaction may technically satisfy the statutory requirements, any underlying fiduciary breach remains subject to redress outside the statute. ${ }^{173}$

1-25(a)(1) (1982); W1s. StaT. ANN. § 180.355(1) (West Supp. 1981-1982); WYo. STAT. § 17-1136.1(a)(i) (Supp. 1982).

170. See Conn. Gen. Stat. Ann. § 33-323(a) (West 1960 \& Supp. 1982); Del. Code ANn, tit. 8, § 144(a)(1) (1974); GA. Code ANn. § 22-716(a)(1) (1977); KAN. STAT. ANN. § 17-6340(a)(1) (1981), LA. Rev. Stat. ANN. § 12:84(A)(1) (West 1969); Ohlo Rev. Code ANN. § 1701.60(a)(1) (Page 1978); OKLA. Stat. tit. 18, $\$ 1.175(a)(1)$ (West Supp. 1980-1981); Pa. Cons. Stat. ANN. § 1409.(A)(1) (Purdon Supp. 1982-1983); R.I. GEN. Laws \& 701.1-37.1(a)(1) (1969 \& Supp. 1981).

171. California enacted the first conflict of interest statute in 1931 to liberalize case law that invalidated transactions between a corporation and its directors solely because a director had an interest in the transaction. See Ballantine, Questions of Policy in Drafting Modern Corporation Law, 19 CAL1F. L. REV. 465, 475-76 (1931). Other states enacted similar provisions to provide greater flexibility and certainty in self-dealing transactions. See generally Bulbulia \& Pinto, Statutory Responses to Interested Directors' Transactions: A Watering Down of Fiduciary Standards?, 53 Notre Dame LAW. 201 (1977); Marsl, Are Directors Trustees? Confict of Interest and Corporate Morality, 22 Bus. LAw. 35, 46-48 (1966); Note, The Status of the Fairness Test Under Section 713 of the New York Business Corporation Law, 76 ColuM. L. Rev. 1156, 1166-74 (1976); Note, Corporations: Interlocking Directorates: Statutory Regulation of Dealings Between Corporations with Inter. locking Directorates, 23 CORNELL L.Q. 445 (1938).

172. See supra notes $169 \& 170$ (statutes cited).

173. In only one case has a court held that a self-dealing transaction which satisfied the state conflict of interest statute implicated the directors in a breach of their fiduciary duty. See Remillard Brick Co. v. Remillard-Dandimi Co., 109 Cal. App. 2d 405, 241 P.2d 66 (1952). Despite the court's holding, it is not clear that the transaction in Remillard Brick did in fact meet the statutory requirements. The California provision required that stockholder approval of a self-dealing transaction be in "good faith," but the defendants in Remillard Brick obtained stockholder approval of the transaction only because they held proxies to vote a majority of the shares. 
Therefore, the policy behind state conflict of interest statutes does not justify the imposition of stricter standards of review in self-dealing cases.

Furthermore, if the directors in a self-dealing case reject a demand for suit or if a committee recommends dismissal, this retrospective approval of a self-dealing transaction does not carry the same presumptive weight as director approval in accordance with a conflict of interest statute. In an attack on a self-dealing transaction that has been authorized by mdependent directors in accordance with a state conflict of interest statute, the transaction is presumed valid, and the plaintiff bears the burden of proving otherwise. ${ }^{174}$ By contrast, if a committee recoinmends that a derivative suit be dismissed, the directors bear the burden of proof. Therefore, the policies behind a state conflict of interest statute are not threatened even if the transaction did not satisfy the statute, and the directors are permitted to authorize dismissal of the suit. In such cases, the transaction cnjoys no presumption of validity.

3. Undue Deference to the Pleadings. Professors Coffee and Schwartz have also argued that when the derivative suit alleges selfdealing by a controlling stockholder, the court must disregard the special hitigation committee's recommendation that the suit be dismissed.175 Coffee and Schwartz argue that the scope of Burks $v$. Lasker ${ }^{176}$ should be limited so that the special hitigation committee can not prevent the derivative suit from performing its historical function of enforcing the duty of loyalty. ${ }^{177}$ This is a most puzzling justification.

If the special hitigation committee is a properly functioning instrument, satisfying the many requirements laid down for it by Professors

Other courts that have reviewed the fairncss of a self-dealing transaction that satisfies the state conflict of interest statute have upheld the transaction. See Scott v. Multi-Amp. Corp., 386 F. Supp. 44 (D.N.J. 1974); Hadden v. Krevit, 186 Conn. 587, 442 A.2d 944 (1982); Fliegler v. Lawrence, 361 A.2d 218 (Del. 1976); Aronoff v. Albanese, 85 A.D.2d 3, 446 N.Y.S.2d 368 (1982). In each of these cases, stockholders, not disinterested directors, had approved the transaction. There is no direct authority to support a court's mdependent review of a transaction's fairness when there has been good faith approval by disinterested directors after full disclosure. At least one state statute, however, expressly authorizes such a review. See CAL. CoRP. CodE § 310(a)(2) II (West 1977).

174. See, e.g., E. Folk III, The Delaware Gen. Corp. Law, A Commentary And AnalyS1S 82-86 (1972); Israels, The Corporate Triangle-Some Comparative Aspects of the New Jersey, New York and Delaware Statutes, 23 Rutgers L. Rev. 615, 627-28 (1969); $c$. WM. CARY \& M. Eisenberg, Corporations Cases and Materials 585-86 (5th Ed. 1980).

175. Section 7.03(c)(iii) of the proposal before the ALI and Coffee and Schwartz's proposed modification of section $49(1)(5)$ of the ModeI Business Corporation Act are substantively identical. See Coffee \& Schwartz, supra note 49, at 334.

176. 441 U.S. 471 (1979). See supra notes $97-109$ and accompanying text.

177. Coffee \& Schwartz, supra note 49 , at 322. 
Coffee and Schwartz, ${ }^{178}$ there should be no residual desire to limit the scope of the committee's action. Under the standards advanced by Professors Coffee and Schwartz, the committee must always have a substantial business justification for its good faith recommendation, the court must concur with the committee's reasoning, and the recommendation inust not conflict with any authoritatively established public policy. Once these requirements are satisfied, it is hardly reasonable to suppose that dismissal of the derivative suit will prevent the redressing of a corporate injury. On the other hand, if the requirements are insufficient to prevent dismissal of cases that are in the corporation's best interest, why single out the subset of loyalty cases for full judicial review?

Coffee and Schwartz's argument seems to presuppose some prejudginent of a case based on the content of the pleadings. Their reasoning is similar to that in the commentary to the proposal before the ALI, which posits a spectrum of corporate wrongdoing and classifies cases by the type of wrongdoing involved. Cascs in which plaintiffs have historically enjoyed little chance of recovery, such as challenges to business decisions, occupy one end of the spectrum; cases in which the plaintiffs have had greater success, such as self-dealing cases, occupy the other. ${ }^{179}$ Determinations of the requisite level of judicial deference to committee recommendations are then resolved by the location of the complaint in the spectrum of cases; ${ }^{180}$ suits that allege self-dealing by a controlling stockholder lie at the far end of the spectrum where no deference is due. Under this analysis, Jack Booth as aider and abettor of another defendant could be shielded from liability by a committee's recommendation of dismissal, but complaints against him as a misappropriator of assets could not be similarly deflected. The reason for regarding the committee inore cynically in the one imstance than in the other lies solely in the nature of the charges leveled by the complaint. The inerit of this type of analysis is not intuitively obvious.

A well-reasoned opmion by Judge Seitz in Lewis v. Curtis ${ }^{181}$ recently denied that important procedural determinations may turn on the nature of the coinplaint. Judge Seitz offered guidelines for formulating standards by which to determine whether a demand on the board should be excused. The standards apply equally to the question of the appropriate degree of deference due a committee's recommendation.

178. See id. at 333-34.

179. CoRporate GovernanCE, supra note $21, \S 7.03$ comment a, at 304,307 and comment c at 321 .

180. See, e.g., Id. $\$ \$ 7.03,7.06$ (c) \& (d).

181. 671 F.2d 779 (3d Cir.), cert. denied, 51 U.S.L.W. 3258 (U.S. Oct. 5, 1982). 
Under Judge Seitz's guidelines, the ultimate concern is whether the facts alleged warrant a court's refusal to defer to the board's (or the committee's) decision not to pursue the claim. ${ }^{182}$ In Lewis, the defendants sought a ruling that would have accorded directors greater freedom to cause a suit's dismissal if the plaintiff failed to plead director conduct that was facially improper. Judge Seitz concluded that to make the directors' power contingent on the nature of the complaint would impermissibly create a pleadings defense to the factual dispute. ${ }^{183}$

Similarly, the availability to the corporation of a special litigation committee, and the impact of its recommendation, should depend not on the plaintiff's allegations, but on the court's factual determination that the committee can regard the defendants impartially. The standard offered to the ALI for testing the committee inembers' independence, its extension of the court's review to all derivative suits against fiduciaries, and its allocation of the burden of proof to the corporation offer a sound framework within which this determination can be inade. The failings of the proposal before the ALI are the substantive limitations it imposes'on this framework based on the nature of the plaintiff's pleadings. The goal of the proposal should be to establish procedures and standards by which the court can decide whether the directors speak for the corporate interest. Instead, Professor Coffee appears intent on assuring prosecution of actions that fall within certain poorly conceived categories, regardless of the action's harm or benefit to the corporation.

\section{Who SPEAKs for the Corporation: A Proposed Cure for STRUCTURAL Bias}

The deinand requirement and the special hitigation committee are devices that enable the corporation to express its interest in the continuation or dismissal of the derivative suit. Whether the directors' voice should be viewed as the legitimate voice of the corporation depends on the court's belief that the directors are sufficiently detached from the defendants and the underlying cause of action to render a bona fide" recommendation. Detailed requireinents, such as those proposed to the $\mathrm{ALI},{ }^{184}$ can define director independence so as to eliminate froin the decisionmaking group directors who have significant family or business relationships with the defendant, who have been substantively impli-

182. Id. at 785,786 .

183. Id. at 786 .

184. See CORPORATE GovernaNCE, supra note $21, \$ 7.03(\mathrm{e})$ (discussed supra note 35). 
cated in the alleged misconduct, or who may have been selected for board membership by the defendants after the suit began. Such limitations, however, reach only the most obvious causes of director bias. The more subtle malady of structural bias cannot be treated solely by notimg suspect relationships and the inanner of the directors' appointment. Whether the directors' impartiality should be questioned further depends on whether structural bias is perceived as real or imagined, and whether, if it exists, it does in fact distort directors' evaluations of the derivative suit. The proposal that follows assumes that structural bias is inherent to the directors' decisionmaking and can, but admittedly does not always, have a significant impact on their recommendation.

The overriding concern in evaluating a committee's recommendation is to determine the corporation's true interest im the derivative suit. Both Zapata and the proposal before the ALI suggest that the corporation's interest in dismissal may be subordimated to an authoritatively established public policy, but this suggestion thwarts the derivative suit's historical mission of redressing corporate injuries and forces courts to make questionable public policy determinations. Concern for the corporate interest must be the foundation for any pretrial scrutiny of the probable benefits of the suit's continued prosecution. Otherwise, the courts could freely ignore the directors' recommendations and allow the litigation to pursue an uninterrupted course.

The most effective remedy for structural bias is to require the courts to take a more active role in their review of the directors' recommendation than Zapata advocates. ${ }^{185}$ Instead of simply ascertaining that there is a reasonable basis for the directors' recommendation, a court should use its own independent judginent to determine whether dismissal would be in the corporation's best interest. ${ }^{186}$ The court should make its decision after an adversarial proceeding that is carefully tailored to avoid consuming the corporation's resources through too lengthy an investigation. The purpose of these hearings would be to assure a close review of the directors' findings and conclusions. The burden of proof should be on the directors, not only because there may be doubt as to their unwavering devotion to the corporation's interests, but also because they have unlimited access to inforination that bears on the commercial interests allegedly served through dismissal. Of course, the directors should be required to meet at least a threshold

185. This assumes, of course, that Zapata only requires the court to examine the facts supporting the committee's decision not to conduct its own inquiry into the merits of the suit. See supra notes $79-92$ and accoinpanying text.

186. See supra text accompanying note 90 . 
standard of independence, such as that in the proposal before the ALI, so that they are not overly involved with the defendants or with the underlying cause of action. This level of independence is not sufficiently persuasive, however, to relieve the directors of the burden of proof or to prevent the court from exercising its independent judgment. Nevertheless, the directors' independence is not insignificant; if the threshold standard is inet, the court need not hesitate to carefully proscribe the areas for preliminary discovery on the suit's merits as well as the length and boundaries of any preliminary hearing. The court should also consider the directors' independence in weighing the soundness of the committee's reasoning.

In their review of the committee's recommendation, courts should not be constrained by the character of the alleged misconduct or by the defendant's status. The threat of structural bias is no greater in derivative suits that allege self-dealing or in suits against the controlling stockholder than in other types of derivative suit litigation. Furthermore, conflict of interest statutes need not bar the directors' decision that a derivative suit that alleges self-dealing should be dismissed.

It is arguable that this approach should also apply when a court reviews a board's rejection of a demand for suit. The considerations that support judicial deference to a commercial decision of the board are not present when the directors' decision pertains to the continuation of a derivative suit. It is inconsistent to subject the special litigation committee's recommendation to higher scrutiny than is given to a decision of the full board of directors. Although Zapata is distinctive for its sensitivity to director bias, ${ }^{187}$ it adopts the conventional view that the board's decision to reject a deinand should be protected by the business judginent rule. ${ }^{188}$ Zapata thus requires a higher level of scrutiny in cases in which the demand is excused and in which a special litigation committee recommends dismissal, but permits a lower level of review when a demand is required and rejected. ${ }^{189}$

The court in Zapata nay have assumed that the directors can be expected to rise collectively above the pressures of structural bias when a demand is required because the majority is not affiliated witl the cause of action. ${ }^{190}$ This mistaken assumption gives rise to several

187. See Zapata Corp. v. Maldonado, 430 A.2d 779 (Del. 1981).

188. Id. at 787 n. 10 .

189. Id. at 787 .

190. See Stein v. Bailey, 53I F. Supp. 684 (S.D.N.Y. 1982). Even though a majority of the directors were independent, the Stein court placed on the committee the burden of proving its independence because the committee was a minority of the board. Id. at 692. The protection of the business judgment rule may therefore be unwarranted if the majority relies on a report pre- 
equally mistaken conclusions. First, it follows that the committee's recommendation should escape Zapata's higher standard of review and be within the protections of the business judgment rule if the coinmittee included not less than a majority of the full board;191 the committee would then have the critical inass necessary to protect its inembers from retaliation. Second, if the suit were against the company's controlling stockholders, the threat of retaliation would require the court to ignore the committee's recommendation even if a majority of the directors were on the committee. ${ }^{192}$

The requirement that the committee have a critical mass of independent meinbers to overcome the threat of retaliation arises from too narrow a perspective on the forces that underlie director bias. To be sure, directors can be expected to be less imdependent if they fear that a decision adverse to their colleagues' interests will cost thein the perquisites of a corporate directorship. The threat of retaliation, however, is by no means the sole source of the directors' structural bias. Structural bias is an attitude that attaches to a directorship and rests on cultural ties that antedate the director's election or appointment, which combime to draw the directors to the defendants' side. Therefore, unless it is assumed that director bias arises solely out of a fear of retaliation, ${ }^{193}$ there is little reason to vary the degree of judicial review of the directors' recommendation simply because the independent directors are a majority or a minority of the board.

pared by a committee composed of a minority of the board. See Abramowitz v. Posner, 672 F.2d 1025 (2d Cir. 1982).

191. Some would argue, however, that a court should not consider the recommendation of even an expanded committee unless a majority of all the directors are independent. See Coffce \& Schwartz, supra note 49 , at $320-26$.

192. Cf. Clark v. Lomas \& Nettleton Fin. Corp., 625 F.2d 49 (5th Cir. 1980). Similarly, some courts have excused a demand on the board because the defendants had the undisputed power to elect directors to office. For example, in de Hass v. Empire Petroleum Co., 286 F. Supp. 809 (D.D.C. 1968), aff'd, 435 F.2d 1223 (10th Cir. 1970), two of the five directors were clearly under the defendant's control. The remaining directors stated in depositions that they were not under the defendant's control and that they would take whatever action was in the corporation's best interest. The court nevertheless excused the deinand on the basis of the defendant's control of the board, even though the directors had voted contrary to the defendant's wishes on previous occasions. Id. at 814 . The result is criticized in Note, The Demand and Standing Requirements in Stockholder Derivative Actions, 44 U. CHI. L. REv. 108, 124 (1976). The more prevalent view is contrary to the holding in de Hass. The demand requirement is usually not excuscd even if the defendant owns a controlling block of stock unless there are also specific allegations that the defendant actually exercises control over the directors' decisions. See, e.g., Greenspun v. Dcl E. Webb Corp., 634 F.2d 1204, 1209 (9th Cir. 1980); In re Kaufman Mut. Fund Actions, 479 F.2d 257, 264 (Ist Cir.), cert. denied, 414 U.S. 857 (1973); Kusner v. First Pa. Corp., 395 F. Supp. 276, 284 (E.D. Pa. 1975); Boyko v. Reserve Fund, Inc., 68 F.R.D. 692, 694-95 (S.D.N.Y. 1975); Stepak v. Dean, 434 A.2d 388, 390-91 (Del. Ch. 1981); Greenspun v. Lindley, 44 A.D.2d 20, 352 N.Y.S.2d 633, 638 (1974), affd, 36 N.Y.2d 473, 369 N.Y.S.2d 123, 330 N.E.2d 79 (1975).

193. See, e.g., Zapata Corp. v. Maldonado, 430 A.2d 779, 786-87 (Del. 1980). 
The special litigation committee poses no mortal threat to the continued existence of derivative suit litigation. To the contrary, the advent of the special litigation committee may serve a constructive function by stimulating serious reconsideration of the court's pretrial role in evaluating the corporation's interest im a derivative suit's dismissal. The recent origin of the special litigation committee offers the courts an opportunity to examine the corporate interest served by a suit's dismissal unburdened by precedent and unconfined by statute. The questionable aspects of Zapata and the proposal before the ALI do not erode their significance in calling attention to the serious consequences of giving any body of directors the power to speak for the corporation's interest in a derivative suit against their colleagues. Now that the problem has been openly recognized, courts should be encouraged to take a less passive role, not only when they respond to a special litigation committee's recommendation, but whenever they review the directors' involveinent im the proposed dismissal of a derivative suit. Structural bias nay be easier to disceru in the recommendation of a special litigation committee, but it is equally present, and equally probleinatic, when the directors refuse a demand for suit or approve an out-of-court settlement. When the directors opine that a derivative suit nust be dismissed, only the court can have sufficient detachment to evaluate legitimately whether the corporate interest would be better served by its contmuation. 
.

$\ddots$ 